\title{
Arsenic Stress Responses and Accumulation in Rice
}

\author{
Varunseelan Murugaiyan, Frederike Zeibig, Mahender Anumalla, \\ Sameer Ali Siddiq, Michael Frei, Jayaseelan Murugaiyan, and Jauhar Ali
}

\begin{abstract}
Rice (Oryza sativa L.) is one of the world's most vital staple grains, and $90 \%$ of it is produced and consumed in Asia alone. It plays a significant role in the entry of mineral nutrients into the food chain. Arsenic (As) is a toxic heavy metal that threatens the major rice-growing regions in the world, particularly in Asia. Arsenic is ubiquitously present in moderate concentrations in the environment because of natural geological processes and anthropogenic impacts. However, rapid industrialization and excessive use of arsenic-rich groundwater are further fueling the increased arsenic concentration in agricultural topsoil. Arsenic accumulation in rice plants has a significant adverse effect on plant, human, and livestock health. Although arsenic contamination in rice is well documented, its interaction and accumulation in rice are poorly understood. So far, no candidate genes or QTLs associated with arsenic interaction are used in breeding programs for the development of low-arsenic-accumulating rice varieties. The development and adaptation of new low-arsenic-accumulating rice cultivars resilient to arsenic toxicity constitute safe
\end{abstract}

\footnotetext{
V. Murugaiyan · F. Zeibig

Rice Breeding Platform, International Rice Research Institute (IRRI), Los Baños, Philippines

Institute of Crop Sciences and Resource Conservation (INRES), University of Bonn,

Bonn, Germany

M. Anumalla

Rice Breeding Platform, International Rice Research Institute (IRRI), Los Baños, Philippines

S. A. Siddiq

University of Minnesota, Minneapolis, MN, USA

M. Frei

Institute of Crop Sciences and Resource Conservation (INRES), University of Bonn,

Bonn, Germany

Department of Agronomy and Plant Breeding, Justus Liebig University, Giessen, Germany

J. Murugaiyan

Department of Biotechnology, SRM University-AP, Amaravati, Andhra Pradesh, India

J. Ali $(\triangle)$

Hybrid Rice Breeding Cluster, Hybrid Rice Development Consortium (HRDC), Rice

Breeding Platform, International Rice Research Institute (IRRI),

Los Baños, Laguna, Philippines

e-mail: J.Ali@irri.org
} 
ways to mitigate arsenic contamination in rice. Recent scientific advances in rice genetics, genomics, and physiology have opened up new opportunities to speed up the process of developing low-arsenic-accumulating rice cultivars for the rapidly growing human population.

Keywords Heavy metal · Arsenic contamination · Arsenic speciation · Phytotoxicity · Quantitative trait loci · Genes

\section{Introduction}

Rice (Oryza sativa L.) belongs to the grass family (Poaceae). Its domestication is one of the most significant events in the history of human agricultural advancement (Khush 1997; Molina et al. 2011; Huang et al. 2012a). It is one of the world's vital staple grains and plays a crucial role in the entry of mineral nutrients into the food chain (Ali et al. 2018a). The presence of naturally occurring unwanted arsenic (As) metalloid in flooded paddy soil poses a significant threat to rice production and consumers who depend on rice as their primary staple food (Murugaiyan et al. 2019). A total of 23-25\% of the total calories consumed by humans come through the consumption of rice alone (Ashikari and Ma 2015; Yu et al. 2020). As the world population is likely to increase further in the coming decades, keeping rice production sustainable remains a crucial challenge (Ali et al. 2018a). Currently, rice is planted on 166 million hectares worldwide, nurturing some four billion people around the world, and the annual harvest of rice is worth USD 200 billion (GRiSP 2013). Rice is the primary cereal crop in Asia, where $90 \%$ of the world's rice is produced and consumed (Frei and Becker 2005; Molden 2013). Approximately 480 million metric tons of milled rice are produced annually; China and India alone account for $\sim 50 \%$ of the rice produced and $90 \%$ of this rice production is consumed domestically (Muthayya et al. 2014). Maintaining a favorable rice supply-demand balance in the future depends mostly on the exploitation of the production capacity of the rainfed ecosystem ( $\mathrm{Li}$ and Ali 2017). On about $60 \%$ of the agricultural land in Asia, rice is grown under rainfed conditions (Rao et al. 2015; Ali et al. 2018a). The rainfed ecosystem is the dominant one in the low-income countries of Asia, where demand for rice is projected to remain very high throughout this century ( $\mathrm{Li}$ and Ali 2017). Rice production in rainfed conditions is susceptible to a combination of various biotic and abiotic stresses. Abiotic stresses are the primary factor undesirably affecting crop growth and yield worldwide (Gao et al. 2007). Various abiotic stresses limit rice production in rainfed environments, which comprise $35-45 \%$ of the global rice area (Wu et al. 2014; Li and Ali 2017). Critical abiotic stresses including extreme temperature, drought, submergence, salinity, iron toxicity, nutritional deficiencies, and heavy metal contamination are known to cause severe losses in rice yield and in the quality of the seed produced (Messerschmidt et al. 2002; Li and Ali 2017; Wu et al. 2017). 
Large tracts of paddy soil are directly affected by heavy metal (arsenic, lead, and cadmium) contamination, especially in India, China, and Bangladesh (Das et al. 2008; Chakraborti et al. 2013; Wu et al. 2016). Rice is conventionally produced in flooded paddy fields, which can translocate the unwanted class I carcinogenicarsenic metalloid into the straw and grain (Sayan et al. 2012). An accumulation of arsenic in the rice plant negatively affects plant performance and also threatens the health of consumers and livestock (Carbonell-Barrachina et al. 2015). Himalayan rivers carry arsenic from rock sediments to the densely populated rice-producing regions of South and Southeast Asia, threatening the primary rice-growing belt of Asia. In these areas, rice production is already threatened by climate change with the frequent intrusion of saltwater in the Ganges-Brahmaputra deltaic regions, and extended periods of drought also force farmers to depend on groundwater for irrigating paddy fields (Murugaiyan et al. 2019). This groundwater is naturally enriched because of arsenic-rich aquifers and it acts as an additional source of arsenic in paddy fields. The long-term use of arsenic-rich groundwater for irrigating rice crops has resulted in an increased concentration of arsenic in paddy topsoil, with up to $83 \mathrm{mg} \mathrm{As} / \mathrm{kg}$ being reported in some parts of Bangladesh and the Indian subcontinent (Suriyagoda et al. 2018). Without intervention, this concentration will tend to increase in the coming decades because of the significant dependence on groundwater for rice production. However, rice varieties suitable for growing in arsenic-rich fields have not been developed. Despite this arsenic threat, the major rice-growing countries in Asia need more food for their rapidly growing populations, leaving scientists with the challenge of developing rice varieties that do not accumulate arsenic in the grain and straw. These varieties also need to withstand other abiotic stresses such as drought, salinity, and flooding. Because of global food security and the increasing health-related concerns associated with arsenic exposure through rice, it has become vital to understand arsenic toxicity, the interaction with rice plants, and the physiological mechanisms associated with arsenic accumulation in rice. Recent scientific advances, particularly in genetics, genomics, and crop physiology, have opened up new opportunities to speed up the process of developing highly adaptable rice cultivars that are safe and nutritious for meeting the future food demand of the growing population.

\section{Heavy Metal Contamination}

Heavy metal contamination has become a significant limitation to sustainable crop production. Particularly in rice, it poses a severe threat to human nutrition and food security (Murugaiyan 2019). The presence of toxic heavy metals such as arsenic (As), cadmium $(\mathrm{Cd})$, lead $(\mathrm{Pb})$, and mercury $(\mathrm{Hg})$ in irrigated water systems threatens not only the rice plant but also the populations that depend on rice for their dietary supply. Additionally, feeding rice straw from contaminated paddy fields to cattle leads to an additional entry of these elements into the human food chain. Toxic heavy metals ubiquitously persist at moderate concentrations in the 
environment because of natural weathering of rocks and minerals, and also through anthropogenic impacts, and they tend to translocate in the food chain (Wu et al. 2016). In recent years, heavy metal contamination has increased significantly in agricultural soil because of the frequent use of polluted irrigation water (Clemens and Ma 2016). Various studies have reported that chronic exposure to heavy metals is often associated with cancer and potentially causes neurotoxicity (Vahidnia et al. 2007). Heavy metals cause developmental neurotoxicity, which is concerning since these developmental abnormalities are often irreversible (Mochizuki 2019).

\subsection{Heavy Metal Interaction with the Biological System}

In a biological system, the toxic effects of these metals may be similar even though their sources are distinct (Fig. 1). Lead and cadmium share similar ionic size and charge, which make them behave similarly in the biological system, especially regarding their toxicity for the same or related molecular targets (Pohl et al. 2011). In principle, lead and cadmium mimic essential ions such as calcium $\left(\mathrm{Ca}^{2+}\right)$ and zinc $\left(\mathrm{Zn}^{2+}\right)$ and use their channels to get into the system (Jomova and Valko 2011). Lead and cadmium exposure generally occurs as a result of industrial exposure. At the same time, arsenic has been reported to occur naturally or as a contaminant, mainly with irrigation water, and is often of geographic origin (Abernathy et al. 2001).

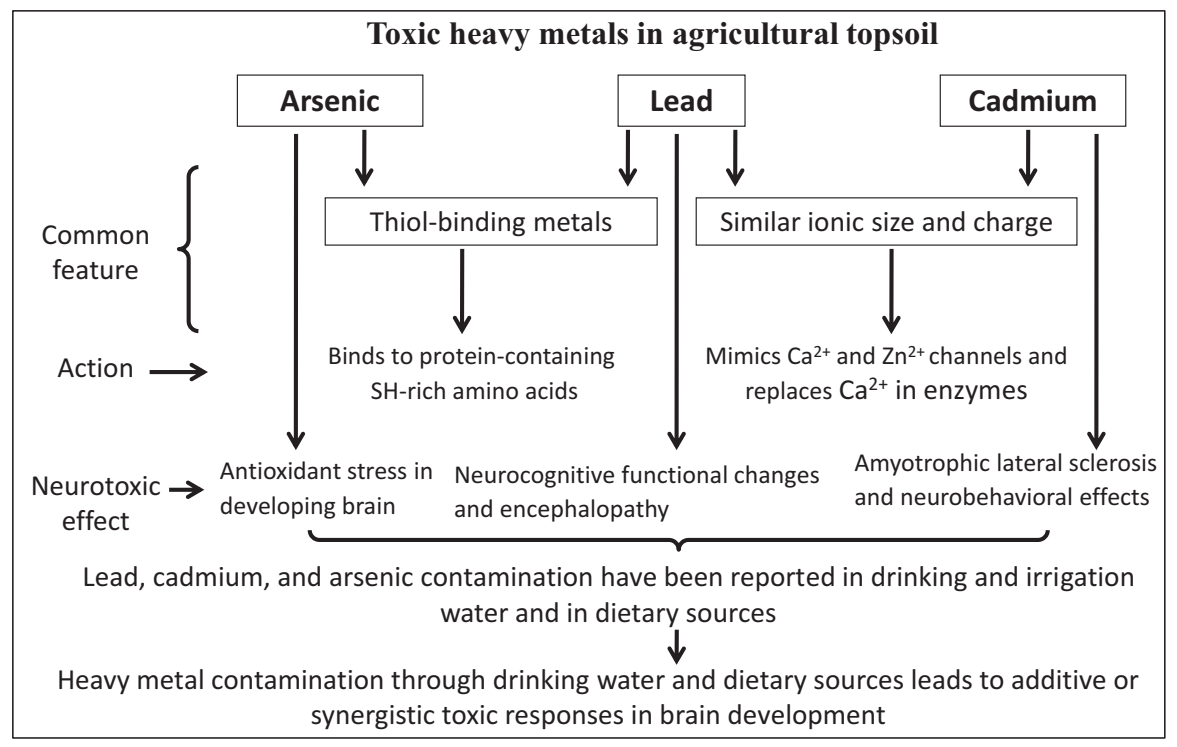

Fig. 1 Similarities between heavy metals and their interaction with the biological system 
Arsenic and lead are known as thiol-binding metals. Hence, both are expected to behave similarly and show similar targets and binding sites (Flora et al. 2011). Arsenic and lead could bind to protein-containing sulfhydryl-rich amino acids such as cysteine residue and could have the same toxic effect. When heavy metals are ingested by humans, the nervous system is a primary target for several of them (Sengupta and Bishayi 2002; Nordberg et al. 2005; Thomas 2013).

\subsection{Chronic Arsenic Exposure and Its Adverse Effects on Human Health}

Arsenic is a metalloid element. It is the 20th most abundant mineral in Earth's crust with an average concentration in sediments ranging from 5 to $10 \mathrm{mg} / \mathrm{kg}$ (National Research Council (U.S.) Committee on Medical and Biological Effects of Environmental Pollutants 1977). Chronic exposure to arsenic is linked with myriad possible adverse health effects on humans, including skin lesions, hypertension, cardiovascular disease, pulmonary disease, reproductive and neurological dysfunctions, hematological changes, and malignancies of skin and internal organs (Mandal and Suzuki 2002). Groundwater arsenic contamination and its ill health effects in Southeast Asian countries came into the limelight in 1984 when groundwater used for drinking purposes was directly tainted by arsenic from natural sources (Garai et al. 1984; Duker et al. 2005). A substantial part of the Ganga-Meghna-Brahmaputra plain, with an area of $569,749 \mathrm{~km}^{2}$ and population surpassing 500 million, was at risk of mass arsenic poisoning (Das et al. 2008; Chakraborti et al. 2013). The World Health Organization (WHO) has recommended $<10 \mu \mathrm{g} / \mathrm{L}$ concentration of arsenic in drinking water as a safe limit (Muhammad et al. 2010; Kumar and Puri 2012). However, high levels of arsenic contamination through groundwater and their adverse impact on human health have been reported in many countries across the world (Nriagu et al. 2007). The magnitude of this problem is of great concern in Bangladesh, followed by India and China (Nickson et al. 2000; Mohan and Pittman 2007; Guha Mazumder 2015; Tareq et al. 2015). Approximately 85-150 million people in India and Bangladesh are at immediate risk from mass arsenic poisoning through contaminated drinking water (Hossain 2006). Both long- and short-term exposure are hazardous and can lead to skin, bladder, lung, and prostate cancers, cardiovascular diseases, diabetes, and anemia, as well as reproductive, developmental, immunological, and neurological effects (Roy and Saha 2002; Ng 2005; Guha Mazumder 2008). Arsenicosis is a chronic illness linked with drinking water with high concentrations of arsenic over a long period and it commonly occurs in populations exposed to arsenic contamination in their living environment (Mazumder 2003; Sun 2004; Kalia and Flora 2005). 


\section{Arsenic Contamination in Paddy Soil}

Arsenic-containing compounds were used widely in the early twentieth century as pesticides and fungicides, which led to a high-arsenic load in agricultural topsoil and water runoff (Mukherjee et al. 2017). Most arsenic exposures occur through contaminated drinking and irrigation water sources. Arsenic is mainly found in pesticides (lead arsenate, calcium arsenate, and sodium arsenite), herbicides (monosodium arsenate and cacodylic acid and dimethyl arsenic acid), cotton desiccants (arsenic acid), wood preservatives (zinc arsenate and chromium arsenate), and semiconductors (gallium arsenide, indium arsenide, and aluminum gallium arsenide). Arsenic is even used as a desiccant and defoliant in agriculture, and as a by-product in the smelting process, particularly for gold and copper, from coal residues (Järup 2003; Vaughan 2006; Chen et al. 2016). Rivers originating from the higher Himalayas carry arsenic from their rock deposits to the densely inhabited rice-growing regions of South and Southeast Asia, making the primary rice-growing belt of Asia vulnerable to arsenic pollution (Shepherd et al. 2015; Lawson et al. 2016). Climate change is also threatening rice production in these areas. With the frequent occurrence of drought and saltwater intrusion in the Ganges-Brahmaputra deltas of India and Bangladesh, farmers increasingly tap groundwater resources for irrigation (Laha 2017). This groundwater is an additional source of arsenic discharged from the naturally abundant arsenic aquifers (Bondu et al. 2016). Typically, 4-8 mg/kg of arsenic occur in flooded paddy soil, but the concentration increases exponentially in paddy soil throughout the cropping season and can reach $83 \mathrm{mg} \mathrm{As} / \mathrm{kg}$ in parts of Bangladesh and West Bengal regions of India (Abedin et al. 2002b; Zavala and Duxbury 2008). Evidence has emerged in recent years that arsenic-enriched groundwater occurs commonly in other Asian countries, including Cambodia, Myanmar, Pakistan, Nepal, Vietnam, and Japan (Fig. 2) (Smith et al. 2000; Das et al. 2008; Brammer and Ravenscroft 2009; Jiang et al. 2013). In the early 1970s, the use of surface water was abandoned mainly in the Bengal delta in response to severe health effects caused by pathogens, and this unexpectedly resulted in the extensive use of arsenic-contaminated groundwater (Caldwell et al. 2003). Alluvial and deltaic environments are mainly characterized by reducing conditions that cause a high-arsenic release in groundwater (Abernathy et al. 2001; Lee et al. 2008). Arsenic-abundant groundwater is drawn from shallow $(<100 \mathrm{~m})$ depths by domestic and irrigation wells in the Bengal basin aquifer system (Sultana 2013). It has been reported that groundwater from shallow tube wells (12-33 m) contains very high amounts of arsenic. In contrast, the water from deep tube wells (200-300 m) contains lower amounts of arsenic (<50 $\mathrm{g} / \mathrm{L})$ (Hossain 2006). Subsurface mobilization of arsenic is mainly caused by a combination of chemical, physical, and microbial factors, and various mechanisms have been proposed to elucidate arsenic mobilization (Anawar et al. 2003; Amini et al. 2008). Among those, the most widely accepted theories are pyrite oxidation and oxy-hydroxide reduction (Hossain 2006). Arsenic dissolution and release in deltaic regions have been modeled considering the contribution of microbes, organic matter, and paleosol formation (Gorny et al. 2015). 


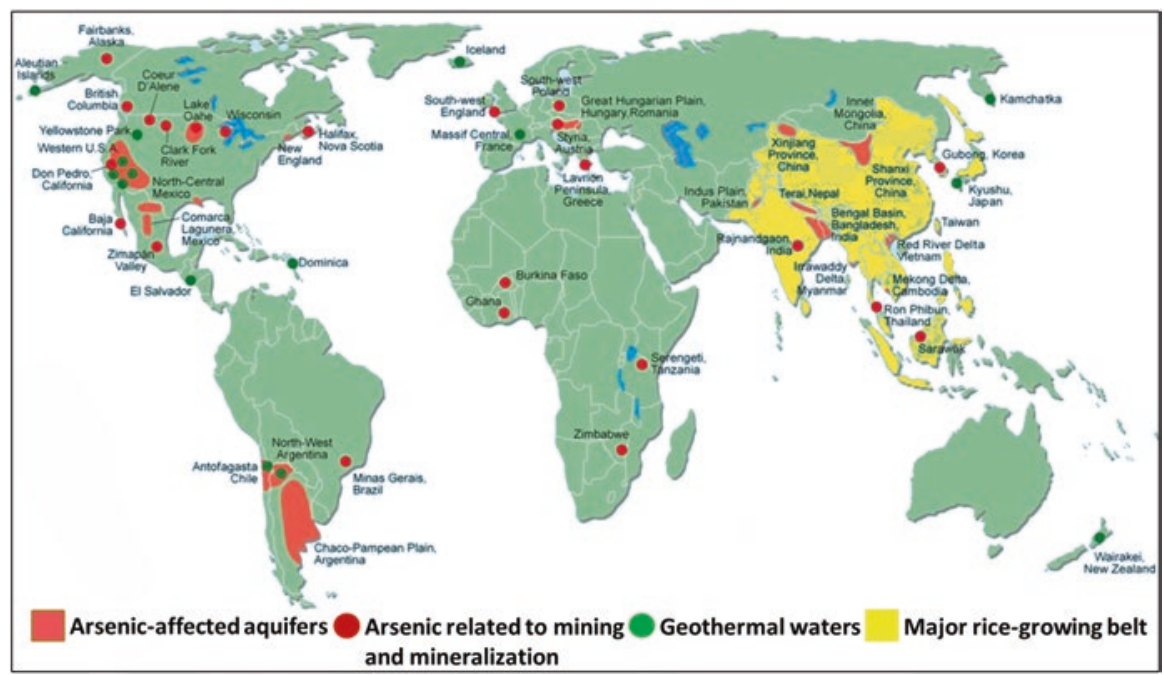

Fig. 2 Worldwide distribution of arsenic-contaminated regions and showing contaminated regions overlapping with major rice-growing belt. (Image modified from the British Geological Survey, Safiuddin et al. 2011)

\subsection{Arsenic Contamination in Rice}

The chemical characteristics of arsenic in paddy soil are complex, as it exists in both organic and inorganic forms, and it differs distinctly under flooded (anaerobic) and non-flooded (aerobic) conditions (Meharg and Hartley-Whitaker 2002). The toxicity of arsenic is associated with reduced soil conditions (flooded soils), which increase the bioavailability of inorganic arsenic and uptake into rice (Zhao et al. 2010b; Islam et al. 2016). Rice is commonly grown in flooded soil under reduced conditions, in which it assimilates inorganic arsenic into its grain, and this accumulation may adversely affect the nutritional quality of the grain (Islam et al. 2016). Of the total arsenic present in rice grain, inorganic arsenic constitutes approximately 54\%. Also, grain arsenic content increases with increased As concentration in paddy soil (Suriyagoda et al. 2018). Total rice grain As concentration can vary from 0.011 to $0.82 \mathrm{mg} / \mathrm{kg}$ on average, depending on location, contamination level, and rice cultivars used (Islam et al. 2016). In highly contaminated areas, arsenic concentration can reach $1.7 \mathrm{mg} / \mathrm{kg}$ in rice grain, which is ten times more than the limit allowed by the WHO in rice grain (Meharg and Rahman 2003). Arsenic content in the rice plant decreases in the order of roots $>$ leaves $>$ grain, and in the rice grain, husk $>$ bran polish $>$ brown rice $>$ raw rice $>$ polished rice $>$ cooked rice (Suriyagoda et al. 2018). A study with a continuous inorganic arsenic treatment showed an increased enrichment of up to $91.8 \mathrm{mg} \mathrm{As} / \mathrm{kg}$ in the straw (Abedin et al. 2002c). About $30 \%$ of the total arsenic taken up by humans was contributed through rice and rice products ( $\mathrm{Li}$ et al. 2011). Furthermore, the straw that cattle feed on will also accumulate arsenic in milk and meat, which are in turn consumed by humans, leading to another route of arsenic exposure (Talukder et al. 2011). 


\subsection{Arsenic Speciation in the Rice Ecosystem}

Arsenic metalloid is ubiquitously found in various inorganic and organic forms in paddy soil. Inorganic arsenic compounds are considered to be highly toxic and they enter into paddy soil through both natural and anthropogenic activities (Sturchio et al. 2013). The toxic effects of arsenic in rice plants depend on their species form, with inorganic arsenic species being more extremely toxic than the organic form. The most common inorganic species that occur in the rice ecosystem are $\operatorname{arsenate}^{(\mathrm{V})}$ and arsenite $^{\text {(III) }}$ (Fig. 3), while the most common organic species are monomethylarsonic acid (MMA) and dimethylarsinic acid (DMA) (Abedin et al. 2002c; Tripathi et al. 2013). Among the inorganic species, trivalent arsenite ${ }^{(\mathrm{III})}$ is considered to be more mobile and toxic than pentavalent $\operatorname{arsenate}^{(\mathrm{V})}$. In both oxidation states, it can combine with methyl groups to form organic arsenic species (Vahter and Concha 2001). However, the existence of organic species in paddy soil is significantly lower than that of inorganic arsenic species. In anaerobic flooded-soil fields (submerged paddy fields), the reduced form arsenite ${ }^{(\mathrm{III})}$ dominates; in aerobic soil conditions, such as upland rice fields, its oxidized form arsenate ${ }^{(\mathrm{V})}$ dominates (Tripathi et al. 2013; Pandey et al. 2015).

\subsection{Inorganic Arsenic Interaction with Essential Plant Nutrients}

Rice plants do not possess naturally evolved arsenic transporters (Pandey et al. 2015). Instead, arsenic competes with chemically similar essential minerals to enter the plant system (Wenzel and Alloway 2013). Arsenite ${ }^{(I I I)}$ is physiochemically

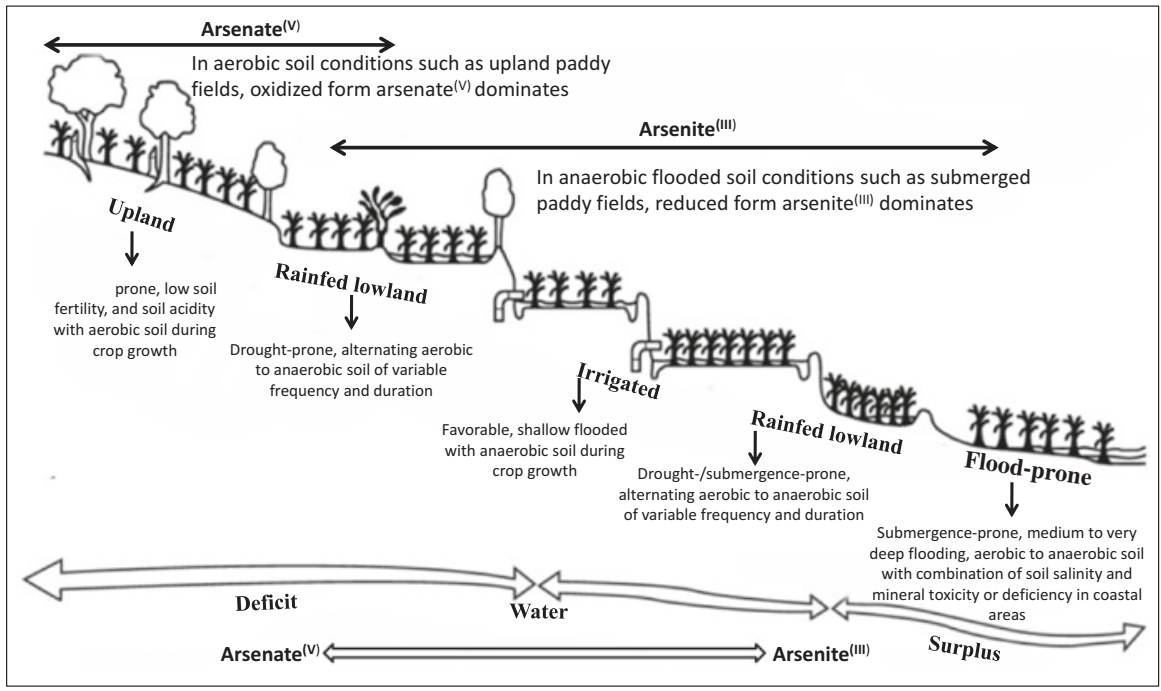

Fig. 3 Inorganic arsenic species found in rice-growing environments. (Adapted and modified from Rice Almanac, 3rd edition, Maclean et al. 2002) 
similar to silica $(\mathrm{Si})$, and thus it competes with the Si-uptake pathway. Silica is not considered an essential nutrient in many plant species. However, silica is uptaken actively by the rice plant due to anaerobic respiration, and the silica content in the rice stem and leaf ranges from 10\% to 20\% (Takahashi 1968; Ma and Takahashi 1990; Dobermann and Fairhurst 2000). Alternatively, arsenate ${ }^{(\mathrm{V})}$ is physiochemically similar to the essential mineral phosphorus $(\mathrm{P})$ and uses $\mathrm{P}$ acquisition pathways to enter the root system, and for efflux toward the xylem and various tissues (Clemens 2006; Zhao et al. 2009; Yang et al. 2018). Most rice genotypes possess a mechanism to retain much of the toxic arsenic burden in the roots. However, a genotypedependent proportion of arsenic is translocated into the shoots and other tissues, including grains of the rice plant (Carey et al. 2010; Pandey et al. 2015). Since $35-55 \%$ of rice is produced in irrigated conditions (Ali et al. 2018b), arsenite (III) contributes to the dominant arsenic species loaded into rice plants (Zhao et al. 2010a).

\section{Arsenic-Induced Toxicity Symptoms During Different Growth Stages of Rice}

Enhanced uptake of arsenic will influence plant growth negatively. Arsenic toxicity in rice plants triggers various symptoms that include lower seed germination rate, poor seed establishment, lower photosynthetic rates, stunted plant growth, low biomass production, sterility-related yield loss, and a physiological disorder referred to as straighthead disease that was associated with arsenic toxicity (Fig. 4) (Rahman et al. 2008; Zhao et al. 2013). Symptoms are often confounded with other soilrelated problems associated with rice (Abedin et al. 2002b; Rahman et al. 2008; Zhu et al. 2008).

\subsection{Germination Stage}

Germination is one of the most delicate stages in a plant's growth cycle. It can be easily affected by abiotic stresses such as drought, salinity, and heavy metals (Rajjou et al. 2012). In general, its starting point is defined with the imbibition of dry seed via water uptake and its termination by radicle or coleoptile appearance (Bewley 1997). A unique feature of rice is the ability to germinate in anaerobic conditions in which the coleoptile occurs first, followed by the radicle. During this process, various complex physiological and biochemical processes take place, for example, the synthesis and degradation of phytohormones, especially abscisic acid (ABA) and gibberellic acid (GA), reactivation of metabolism, and hydrolyzation of starch via enzymes for maintaining a source of energy (Seneviratne et al. 2019). He and Yang (2013) summarized the three phases of germination and their ongoing processes. During phase one, water is taken up rapidly into the seed, where the biosynthesis of mRNA starts, followed by starch degradation. In phase 2, the 


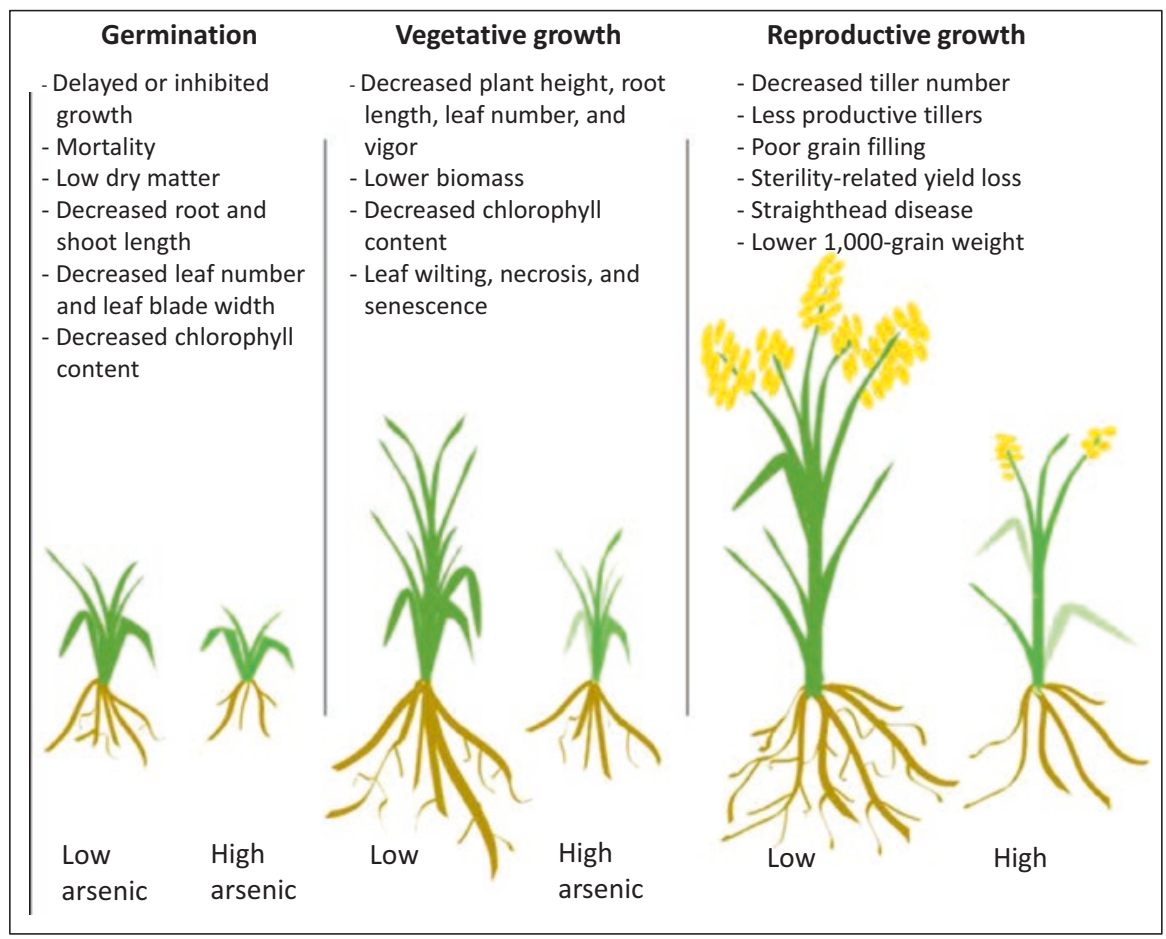

Fig. 4 Arsenic-induced symptoms during the different growth stages in rice

reactivation of metabolism begins, involving starch hydrolysis, glycolysis, and fermentation for mobilizing reserves, accompanied by amino acid biosynthesis, non-functional protein degradation, and mitochondria assembly. In the third phase, the conversion of carbohydrates to sugars begins, and the embryo is activated. The last step is coleoptile emergence, which is accompanied by the onset of aerobic respiration (He and Yang 2013). Especially in phase 1 and 3, water is taken up rapidly (Bewley 1997). With the background of arsenic-contaminated water, this implies that the seed and its emerging seedling confront arsenic stress. This may lead to an interruption or alteration in the normal germination process (Seneviratne et al. 2019). Germination of seeds was delayed or inhibited when the seeds were grown in a nutrient solution with more than $5 \mathrm{ppm}$ arsenic (Begum and Mondal 2019). When seedlings were grown in pots filled with arsenic-contaminated soil, their mortality was observed at $40 \mathrm{mg} / \mathrm{kg}$ arsenite ${ }^{(\mathrm{III})}$ in aerobic and anaerobic conditions, but it was higher in the anaerobic treatment (Shah et al. 2014). Those different observations could be explained by different experimental setups, different growth media, or because two different varieties were tested in the studies: IET-4786 and BRRIdhan28. When the seeds were able to germinate, they showed lower dry matter and decreased shoot and root length (Begum and Mondal 2019). A lower number of leaves and a lower leaf blade width were also observed as a consequence 
of arsenic treatment (Shaibur et al. 2006). Also, the chlorophyll content of seedling leaves decreased, irrespective of whether the plants were treated with arsenate ${ }^{(\mathrm{V})}$ or arsenite $^{\text {(III) }}$ (Shaibur et al. 2006; Choudhury et al. 2011; Begum and Mondal 2019). As a general observation, arsenite ${ }^{(I I I)}$ treatment always caused more toxic symptoms on seedlings than $\operatorname{arsenate}^{(\mathrm{V})}$ (Shah et al. 2014; Begum and Mondal 2019).

\subsection{Vegetative Growth}

The same symptoms as for the seedlings keep occurring during the vegetative growth phase of the rice plant. Decreased plant height was most commonly observed (Abedin et al. 2002b; Shah et al. 2014; Dixit et al. 2016) as well as decreased root length and vigor (Abedin et al. 2002a; Das et al. 2013). Symptoms resulted from a change in IAA biosynthesis and transport, which is responsible for the formation of auxin. Lower auxin content then influenced root development, especially of the lateral roots (Ronzan et al. 2018). The resulting symptom of decreased biomass (Abedin et al. 2002b) was caused by an alteration in photosynthesis (Tuli et al. 2010). Arsenic toxicity degenerated the membrane structure and therefore affected the chloroplast as well as photosynthetic processes (Begum and Mondal 2019). The leaves wilted and turned violet due to increased anthocyanin content (Hossain 2006). As a consequence, leaf tips and margins developed senescence and eventually necrosis (Das et al. 2013). Because of these symptoms, a lower photosynthetically active area occurred, which resulted in lower energy for the plant's metabolism, leading to decreased plant height and stunted growth.

\subsection{Reproductive Growth}

The changes in the metabolism of the rice plant described in the previous section led to lower yield (Shah et al. 2014). Total yield loss was $80 \%$ when the soil contained more than $60 \mathrm{mg} \mathrm{As} / \mathrm{kg}$, but a significant loss was observed from $15 \mathrm{mg} \mathrm{As} / \mathrm{kg}$ (Das et al. 2013). Yield decreased because of lower tiller number, which was observed in a treatment of $40 \mathrm{mg} / \mathrm{kg}$ arsenite ${ }^{(I I I)}$ in a pot study (Das et al. 2013; Shah et al. 2014). This caused a lower number of filled and mature grains per panicle (Das et al. 2013). Another physiological disorder that has been associated with arsenic toxicity is straighthead disease. This physiological disorder produces sterile florets and spikelets and thereby diminishes grain yield (Rahman et al. 2008). A study with arsenate $^{(\mathrm{V})}$-contaminated irrigation water showed rice plants with decreased plant height and grain yield, explained by a lower number of filled grains and grain weight, and lower root biomass. At the same time, there was a significant increase in arsenic concentration in the root, straw, rice husk, and grain (Abedin et al. 2002b). The leaves can wilt and turn violet because of increased anthocyanin content (Abbas et al. 2018). Also, the chlorophyll content of seedling leaves decreased with both 
$\operatorname{arsenate}^{(\mathrm{V})}$ and arsenite $\mathrm{a}^{(\mathrm{III})}$. This observation explains the lower biomass and growth. Finally, leaf tips and margins develop necrosis (Abedin et al. 2002c; Zhao et al. 2009). Roots show decreased biomass and lower root vigor. Grain yield decreases with decreased tiller number, filled grains, and panicles due to the sterility of florets and spikelets (Rao et al. 2011). Concerning metabolism, arsenic affects carbohydrate, lipid, and protein metabolism (Finnegan and Chen 2012). More importantly, arsenic can cause an increased formation of reactive oxygen species (ROS), exceeding the level that can be scavenged, thus leading to oxidative damage in the plant. Hydrogen peroxide $\left(\mathrm{H}_{2} \mathrm{O}_{2}\right)$, and malondialdehyde $\left(\mathrm{CH}_{2}(\mathrm{CHO})_{2}\right)$ were the major ROS formed when rice seedlings were exposed to $\operatorname{arsenate}^{(\mathrm{V})}$ (Rao et al. 2011).

\section{Quantitative Trait Loci Associated with Arsenic Stress Tolerance in Rice}

Arsenic toxicity, uptake, and accumulation in rice represent a quantitative trait governed by multiple loci (Dasgupta et al. 2004; Zhang et al. 2008; Murugaiyan et al. 2019). Genetic improvement by the selection of rice cultivars with a lower concentration of arsenic in the edible parts is vital in the development of rice varieties accumulating low arsenic (Norton et al. 2012; Duan et al. 2017). Even though rice breeders have been particularly interested in developing cultivars accumulating low arsenic for contaminated ecosystems, no promising loci have been functionally characterized for use in their breeding programs. Identification of appropriate rice cultivars and genetic mapping of chromosomal regions associated with a low-arsenic concentration constitute a practical methodology for diminishing the impact of arsenic in rice.

Arsenic interaction with rice has remained well-documented over the past two decades. Several QTLs have been reported in both vegetative tissues and grains (Table 1). More than a decade ago, Dasgupta et al. (2004) proposed the first QTL related to arsenate ${ }^{(\mathrm{V})}$ uptake close to a phosphate $(\mathrm{P})$ uptake QTL on chromosome 6 and named the region AsTol (Dasgupta et al. 2004). This region covers multiple genes with various functions, and it needs to be fine-mapped to identify responsible genes with potential for rice varieties accumulating low arsenic. Nonetheless, chromosome 6 has been identified to harbor several QTLs related to arsenic toxicity, even though these QTLs vary in their physical positions (Dasgupta et al. 2004; Zhang et al. 2008; Norton et al. 2012; Kuramata et al. 2013; Liu et al. 2019; Murugaiyan et al. 2019). QTLs on chromosome 6 were proposed to mediate arsenic concentration in the grain of brown rice (Zhang et al. 2008) and the DNA concentration of the grain (Kuramata et al. (2013). The previously mapped QTLs were closely colocalized to a QTL that mediates leaf arsenic concentration (Norton et al. 2010a). Recently, another QTL responsible for arsenic shoot content was found by Murugaiyan et al. (2019) on chromosome 6 . These results indicated that the regions on chromosome 6 were involved in the uptake of arsenate ${ }^{(\mathrm{V})}$. Several 


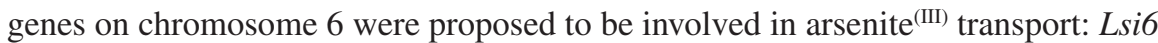
$\left(\mathrm{OsNIP}_{2 ; 2}\right)$ expressed at the grain-filling stage and plasma membrane intrinsic protein (OsPIPI $2 ; 7$ ) (Kuramata et al. 2013; Liu et al. 2019). Murugaiyan et al. (2019) also identified a tolerance QTL ( $q$ RChlo1) on chromosome 1 for relative chlorophyll content in a backcross-selected breeding population of rice, and $q R C h l o 1$ increased the tolerance percentage of rice of arsenite ${ }^{(I I I)}$ stress. However, none of these QTLs and genes has been functionally characterized for use in breeding programs for the development of varieties accumulating low arsenic. Chromosome 5 also contained regions of interest. Norton et al. (2010a) found a QTL associated with arsenic content in leaves on chromosome 5 , but the soil at the study site had a low-arsenic concentration (<1 ppm). Also, Murugaiyan et al. (2019) identified the same QTL region on chromosome 5 for shoot arsenic concentration in a breeding population of rice. A heavy metal-associated domain-containing protein (HMA) was suggested as a candidate gene on chromosome 5. Those HMAs are associated with detoxifying heavy metals by containing a metal-binding domain and they have already been shown to help in the metal homeostasis of copper, zinc, lead, and cadmium

Table 1 QTLs reported in rice for arsenic tolerance and accumulation

\begin{tabular}{|c|c|c|c|c|}
\hline Reference & $\begin{array}{l}\text { Phenotyping } \\
\text { under }\end{array}$ & $\begin{array}{l}\text { As } \\
\text { concentration }\end{array}$ & Population used & $\begin{array}{l}\text { Putative } \\
\text { QTLs on } \\
\text { chromosome }\end{array}$ \\
\hline $\begin{array}{l}\text { Dasgupta et al. } \\
\text { (2004) }\end{array}$ & $\begin{array}{l}\text { Hydroponic } \\
\text { culture } \\
\text { system }\end{array}$ & $\begin{array}{l}1 \mathrm{mg} \mathrm{As} / \mathrm{kg} \\
\text { arsenate }^{(\mathrm{V})}\end{array}$ & $\begin{array}{l}\text { Bala (indica) } \times \text { Azucena } \\
\text { (japonica) recombinant } \\
\text { inbred lines }\end{array}$ & 6 \\
\hline Zhang et al. (2008) & $\begin{array}{l}\text { Pot culture } \\
\text { system }\end{array}$ & $1.27 \mathrm{mg} \mathrm{As} / \mathrm{kg}$ & $\begin{array}{l}\text { CJ06 (japonica) } \times T 1 \\
\text { (indica) doubled- } \\
\text { haploid population }\end{array}$ & $2,3,6,8$ \\
\hline $\begin{array}{l}\text { Norton et al. } \\
\text { (2010a) }\end{array}$ & $\begin{array}{l}\text { Field } \\
\text { conditions }\end{array}$ & $0.32 \mathrm{mg} \mathrm{As} / \mathrm{kg}$ & $\begin{array}{l}\text { Bala (indica) } \times \text { Azucena } \\
\text { (japonica) recombinant } \\
\text { inbred lines }\end{array}$ & $1,3,5,6$ \\
\hline Norton et al. (2012) & $\begin{array}{l}\text { Field } \\
\text { conditions }\end{array}$ & $73.8 \mathrm{mg} \mathrm{As} / \mathrm{kg}$ & $\begin{array}{l}\text { Bala (indica) } \times \text { Azucena } \\
\text { (japonica) recombinant } \\
\text { inbred lines }\end{array}$ & 8,10 \\
\hline $\begin{array}{l}\text { Kuramata et al. } \\
\text { (2013) }\end{array}$ & $\begin{array}{l}\text { Field } \\
\text { conditions }\end{array}$ & $1.4 \mathrm{mg} \mathrm{As} / \mathrm{kg}$ & $\begin{array}{l}69 \text { accessions from } \\
\text { World Rice Collection }\end{array}$ & 6,8 \\
\hline Norton et al. (2014) & $\begin{array}{l}\text { Field } \\
\text { conditions }\end{array}$ & $\begin{array}{l}14 \pm 0.3 \mathrm{mg} \mathrm{As} / \\
\mathrm{kg}\end{array}$ & $\begin{array}{l}312 \text { accessions from } \\
\text { Rice Diversity Panel } 1\end{array}$ & 3,5 \\
\hline Liu et al. (2019) & $\begin{array}{l}\text { Field } \\
\text { conditions }\end{array}$ & $3000 \mathrm{mg}$ As/kg & $\begin{array}{l}276 \text { accessions from } \\
\text { global Rice Diversity } \\
\text { Panel }\end{array}$ & $\begin{array}{l}1,2,4,5,9 \\
11,12\end{array}$ \\
\hline $\begin{array}{l}\text { Murugaiyan et al. } \\
\text { (2019) }\end{array}$ & $\begin{array}{l}\text { Hydroponic } \\
\text { culture } \\
\text { system }\end{array}$ & $\begin{array}{l}10 \mathrm{mg} \mathrm{As} / \mathrm{kg} \\
\text { arsenite }^{(\mathrm{III})}\end{array}$ & $\begin{array}{l}\text { WTR1 }(\text { indica }) \times \text { Hao- } \\
\text { an-nong (japonica) } \\
\text { backcross recombinant } \\
\text { inbred breeding } \\
\text { population }\end{array}$ & $1,2,5,6,8,9$ \\
\hline Norton et al. (2019) & $\begin{array}{l}\text { Field } \\
\text { conditions }\end{array}$ & $4.63 \mathrm{mg} \mathrm{As} / \mathrm{kg}$ & $\begin{array}{l}266 \text { Bengal Assam Aus } \\
\text { Panel }\end{array}$ & $2,3,5,7,9$ \\
\hline
\end{tabular}


(Murugaiyan et al. 2019). However, their metal-binding ability toward arsenic has not been characterized in rice.

Besides chromosomes 6 and 5, chromosome 8 was found to harbor a few QTLs that influence grain arsenic content, colocalizing with a locus affecting shoot phosphorus concentration at the seedling stage of rice (Zhang et al. 2008; Norton et al. 2012; Kuramata et al. 2013). Also, a QTL related to the trait days to heading was found close to a QTL for grain arsenic content on chromosome 8, leading to the assumption that a prolonged time of the vegetative phase could decrease grain arsenic content (Norton et al. 2012). Furthermore, a QTL that mediated grain DNA content was also localized on this chromosome (Kuramata et al. 2013). Chromosome 3 was also identified several times and was proposed to contain a QTL that encompassed Lsi2, a transporter for arsenite ${ }^{(I I I)}$ (Norton et al. 2012, 2019). Nonetheless, it is also important to identify QTLs associated with arsenic uptake as well as translocation, because, if no arsenic enters the plant or is safely stored, no arsenic will reach the grain. QTLs mediating root arsenic concentration were located on chromosomes 3 and 8 (Zhang et al. 2008; Murugaiyan et al. 2019). In order to estimate arsenic uptake and metabolism, measuring root As content was claimed to be a biased evaluation criterion due to arsenic residuals on the root surface (Zhang et al. 2008). More QTLs contributing to shoot arsenic concentration were found on chromosomes 2, 5, 6, and 9 (Zhang et al. 2008; Murugaiyan et al. 2019), and more precisely for the arsenic concentration in leaves on chromosomes 1, 3, 5, and 6 (Norton et al. 2010a). The QTL on chromosome 2 covered 13 candidate genes, including an $\mathrm{H}^{+}$vacuolar pyrophosphatase, which is known to mediate changes in the concentration of essential and toxic ions (Murugaiyan et al. 2019). However, the QTLs mapped for arsenic tolerance in rice are not characterized for use in breeding programs for the development of arsenic-safe varieties.

\section{Arsenic Uptake in Rice}

As previously stated, arsenite ${ }^{(\mathrm{III})}$ is the predominant form of arsenic in paddy soils. In order to develop rice varieties accumulating low arsenic, it is critical to understand the uptake, translocation, and underlying physiology of arsenic interaction with rice (Fig. 5). The uptake kinetics of both inorganic arsenic species were similar and followed the Michaelis-Menten equation (Lou et al. 2009). At higher substrate concentration, arsenite ${ }^{(I I I)}$ had a higher uptake and was therefore assumed to have a low-affinity uptake system (Abedin et al. 2002a). Arsenite ${ }^{(\mathrm{III})}$ and $\operatorname{arsenate}^{(\mathrm{V})}$ have different ionic size and their uptake pathways differ (Zhao et al. 2013). Arsenite(III) resembles the silica ion in diameter and comparable acid-ionization constant value $\left(\mathrm{p} K_{\mathrm{a}}\right)$ (Jian et al. 2008). Arsenate $\mathrm{C}^{(\mathrm{V})}$ has a structure similar to the orthophosphate anion and their second and third $\mathrm{p} K_{\mathrm{a}}$ values are similar (O'Day 2006). Dimethylarsinic acid (DMA) and monomethylarsonic acid (MMA) are the most abundant forms of organic arsenic in paddy soil. They were a result of arsenite methylation facilitated by microorganisms (Wu et al. 2012). The uptake of organic arsenic species was the 
only way for DMA and MMA to enter the rice plant since rice cannot methylate arsenic in planta. Instead, methylation occurred in the presence of methylating microorganisms in the rhizosphere (Lomax et al. 2012). Those microorganisms need to contain the $\operatorname{ars} M$ ( $S$-adenosylmethionine methyltransferase) gene in order to methylate arsenic (Jia et al. 2013).

\subsection{Arsenite Uptake}

Two major transporters were identified for arsenite ${ }^{(I I I)}$ uptake in rice (Fig. 6). These transporters form part of the aquaporins family, belonging to the group of nodulin 26-like intrinsic membrane proteins (NIPs) in rice (Jian et al. 2008). The aquaporins Lsil $(O s N I P 2 ; 1)$ and Lsi2 were permeable only to arsenite ${ }^{(\mathrm{III})}$ and usually mediated silicon influx and efflux. They differed in location and thus in their function. Lsil

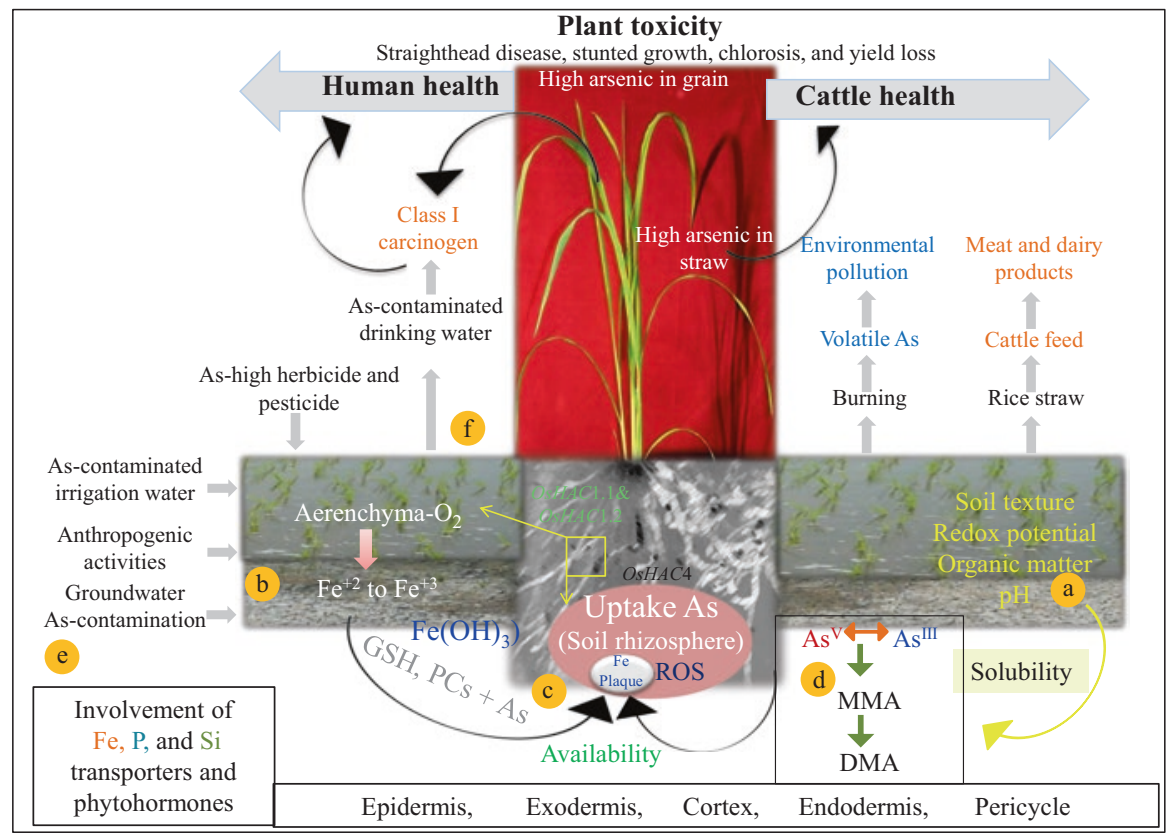

Fig. 5 Factors influencing arsenic availability and transportation from soil to rice plants: (a) the factors involved in solubility and available form of arsenic; (b) anaerobic conditions, rice roots of aerenchyma release a part of the $\mathrm{O}_{2}$ to the rhizosphere complex; (c) formation of iron (Fe) plaques: $\mathrm{Fe}^{2+}$ oxidized to $\mathrm{Fe}^{3+}$ on the root surface and subsequent reaction of sulfhydryl-containing short peptides such as glutathione and phytochelatins binding to arsenic; (d) if more oxygen is released, this also may oxidize $\operatorname{arsenite}^{(\mathrm{III})}$ to $\operatorname{arsenate}^{(\mathrm{V})}$, which is more strongly adsorbed to iron plaque; (e) uptake of arsenate ${ }^{(\mathrm{V})}$ is supported by various micronutrient transporters; (f) As-contaminated paddy soil influenced by different external factors, and effects of consumption of food grain and drinking water on human health 
was responsible for the transport of arsenite ${ }^{(I I I)}$ from the external solution to the root cells. It was located and expressed on the outside of the exodermis and endodermis close to the Casparian stripe. The transport was bidirectional, indicating that arsenite $^{(\text {III) }}$ could also efflux to the external medium via Lsil (Zhao et al. 2010b). However, there were more efflux transporters to be included (Zhao et al. 2010a). Lsi 2 mediated the efflux of arsenite ${ }^{(\mathrm{III})}$ toward the xylem and formed the counterpart of Lsil at the expression site. Lsi2 was expressed on the inner side of the plasma membranes of the exodermis and endodermis. From there, arsenite ${ }^{(\mathrm{III})}$ was released into the cortex and stele. Lsi2 was considered to be more involved in the transport and translocation of arsenite ${ }^{(\mathrm{III})}$ from shoot to grain (Jian et al. 2008). In the stele of primary roots and cell layers of lateral roots, more precisely in the plasma membrane, the membrane protein OsNIP3;2 was expressed, which also belongs to the NIP family. Arsenite ${ }^{(\mathrm{III})}$ was also taken up and further transported through this protein (Chen et al. 2017). Besides the NIPs, plasma membrane intrinsic proteins (PIPs) are likely to play a role in arsenic homeostasis in rice. When exposed to elevated arsenite $^{(\mathrm{III})}$ concentrations, the transcript concentrations in the roots were downregulated in order to prevent an increased arsenic uptake (Mosa et al. 2012).

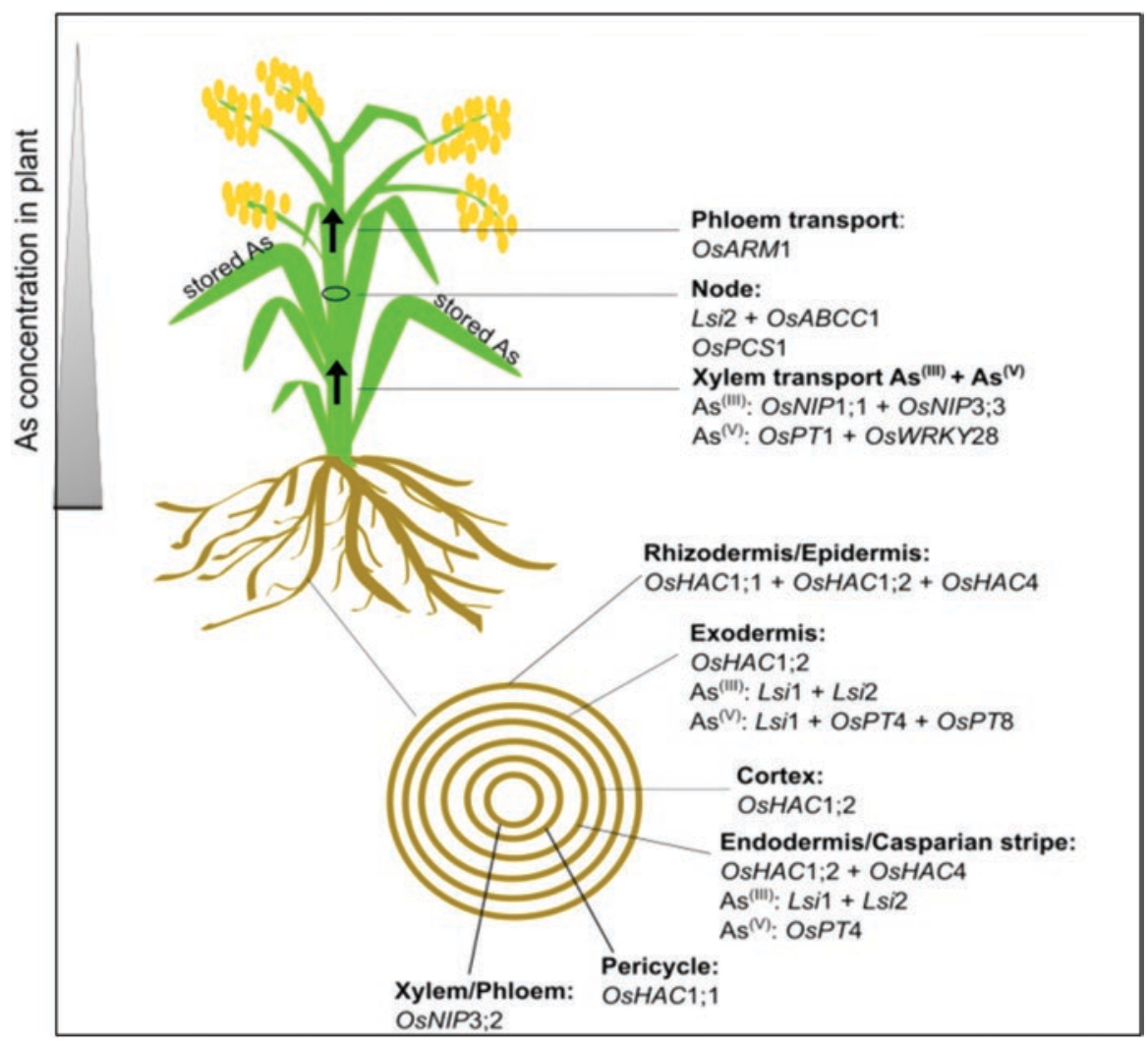

Fig. 6 Schematic representation of arsenic uptake and translocation in rice 


\subsection{Arsenate Uptake}

Arsenate $^{(\mathrm{V})}$ is a chemical analog of phosphate ions and takes advantage of the phosphorus transport pathway. In the presence of phosphate, the uptake of arsenate ${ }^{(\mathrm{V})}$ was actively suppressed, whereas arsenite(III) was not (Abedin et al. 2002a). This finding was a clear indicator that $\operatorname{arsenate}^{(\mathrm{V})}$ used phosphorus transporters $(P h t)$. On a molecular level, the Pht family, comprising 13 genes, was associated with phosphate transport in rice (Wang et al. 2016). Some of the transporter function genes were investigated concerning arsenate ${ }^{(\mathrm{V})}$ uptake. OsPT8 $(O s P h t 1 ; 8)$ mediated phosphorus homeostasis and was also considered as a critical transporter for $\operatorname{arsenate}^{(\mathrm{V})}$ uptake in rice roots (Wang et al. 2016). A role for the uptake and translocation of arsenate ${ }^{(\mathrm{V})}$ in rice was demonstrated by expression analysis of the OsPT4 transporter gene. The overexpression of this gene resulted in higher arsenic accumulation when grown in $\operatorname{arsenate}^{(\mathrm{V})}$ solution (Chao et al. 2014). Lsil also played an essential role in the uptake of arsenate ${ }^{(\mathrm{V})}$ since it was found that arsenite $^{(\mathrm{III})}$ was effluxed through this channel when rice roots were exposed to $\operatorname{arsenate}^{(\mathrm{V})}(\mathrm{Zhao}$ et al. 2010a).

\section{Arsenic Translocation in Rice}

The translocation of arsenic depends on its concentration, its capability of complexation, and its sequestration as well as the xylem flow rate (Suriyagoda et al. 2018). In general, the concentration of arsenic in rice decreases in the following order: root $>$ straw $>$ husk $>$ grain (Abedin et al. 2002b). Translocation of arsenic species from root to shoot to grain also depends on the genotype and growth stage. In general, grain arsenic content was found to be affected by genotype, year, and genotype $\times$ year interaction effects (Kuramata et al. 2013). A higher-yielding variety was found to be capable of translocating more arsenic from root to shoot and also from shoot to grain than traditionally grown landraces (Bhattacharya et al. 2010). Genotypes that varied in grain arsenic accumulation were found to have different arsenic content in all plant tissues (Duan et al. 2011). Furthermore, there was evidence that translocation mainly took place at the active tillering stage (Das et al. 2013).

\subsection{Arsenite Translocation}

The phloem plays a significant role in arsenic translocation from the vegetative tissue to the grain. Arsenite ${ }^{(\mathrm{III})}$ was translocated to the vegetative tissue, capable of being remobilized and transported to the grain through the phloem (Fig. 7). An explanation for this phloem loading might be a transfer of arsenic in the xylem 
vessels into the phloem (Zhao et al. 2012). The phloem transferred $90 \%$ of arsenite $^{\text {(III) }}$ and 55\% of DMA to the grain (Carey et al. 2010). Inorganic arsenic was mostly found in the caryopsis and transported during the grain-filling stage. DMA accumulated in the caryopsis before flowering (Zhao et al. 2012). The mechanism by which arsenite ${ }^{(\mathrm{III})}$ is remobilized and further transported is not known yet. Arsenic could be stored in the nodes and internodes of rice, where arsenic accumulation was observed in the phloem companion cells. From there, translocation to the grain and flag leaf was restricted. This capability of the nodes was explained by a higher expression of Lsi2 and the formation of arsenite ${ }^{(\mathrm{III})}$-thiol compounds in the vacuole (Chen et al. 2016). OsABCCl was also included in the storage of arsenic in the nodes by sequestering it in the vacuoles of the phloem companion cells (Song et al. 2014). The phytochelatin synthase OSPCS1 might play a supportive role in this process, as it reduced arsenic grain contents when overexpressed (Hayashi et al. 2017). In the basal and upper nodes, the transcription factor OsARMI (Arsenite Responsive MYB 1) was strongly expressed in the phloem region when exposed to high-arsenite ${ }^{(\mathrm{III})}$ concentrations. It also showed high expression in the rachis and spikelet and was likely to be involved in mediating uptake and root-to-shoot translocation (Wang et al. 2017). Those findings indicate that translocation through the phloem is more critical than translocation through the xylem.

\subsection{Arsenate Translocation}

It is widely assumed that $\operatorname{arsenate}^{(\mathrm{V})}$ is directly reduced to arsenite ${ }^{(\mathrm{III})}$ in the root. Seyfferth et al. (2011) showed that oxidized arsenic species were the predominant form in the xylem within a root cross-section. This was supported by the assumption that the uptake of the two inorganic arsenic species occurred at different locations in the root. However, genotype-dependent variation was also observed (Seyfferth et al. 2011). Another fact that disproved the reduction assumption was that straw contained mostly arsenate ${ }^{(\mathrm{V})}$ after growing in an $\operatorname{arsenate}^{(\mathrm{V})}$ solution for 170 days (Abedin et al. 2002a). The high abundance of arsenate ${ }^{(\mathrm{V})}$ could be explained by the limited capacity of the reducing enzymes $O s H A C 1 ; 1$ and $O s H A C 1 ; 2$, thus not reducing $\operatorname{arsenate}^{(\mathrm{V})}$

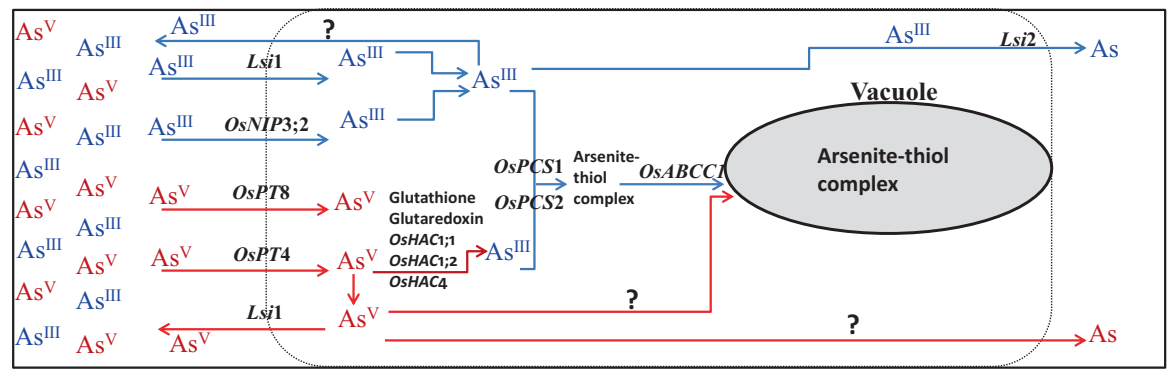

Fig. 7 Schematic representation of arsenic uptake and storage in a cell 
anymore (Shi et al. 2016). Nonetheless, as soon as inorganic arsenic was in the xylem, it became transported to the vegetative parts. Nodulin 26-like intrinsic membrane proteins that were included in the translocation of arsenite ${ }^{(I I I)}$ from root to shoot included $O S N I P 1 ; 1$ and $O S N I P 3 ; 3$, which caused a decreased arsenic concentration in shoot and xylem when overexpressed. OsNIP1; 1 was expressed in the basal stem at the seedling and tillering stages. At maturity, it was mostly expressed in the roots, basal stem, nodes, and spikelets. In contrast, OsNIP3;3 was expressed continuously in different tissues (Sun et al. 2018). For the transport of arsenate $^{(\mathrm{V})}$ from root to shoot, the expression level of $O s P T 1$ was investigated. It

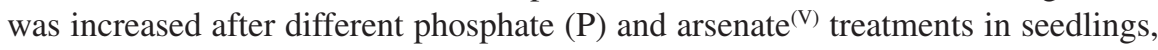
which indicated its facilitating role for the transport (Kamiya et al. 2013). OsWRKY28, a transcription factor of the WRKY family that is mostly involved in stress tolerance, was found to contribute to the translocation of arsenate ${ }^{(\mathrm{V})}$ from root to shoot (Wang et al. 2017).

\section{Arsenic Detoxification and Stress Responses in Rice}

Arsenic does not have any known biological function within the rice plant, and enhanced uptake triggers various defense mechanisms in the plant to mitigate the negative impact of arsenic stress. Once $\operatorname{arsenate}^{(\mathrm{V})}$ was taken up into the cell, it was reduced to arsenite ${ }^{(I I I)}$, which was the dominant form inside the plant tissue (Ali et al. 2009). The reduction was a slow process mediated by glutaredoxin (Suriyagoda et al. 2018). Enzymatic reduction of arsenate ${ }^{(\mathrm{V})}$ was performed more likely by the arsenate $^{(\mathrm{V})}$ reductase gene High Arsenic Content (HAC) (Chao et al. 2014). In rice, OsHACl;1, OsHACl;2, and OsHAC4 played a significant role in this process (Shi et al. 2016). They were most commonly expressed in the roots. OsHACl;1 was found in the epidermis, pericycle cells, and root hairs in the mature zone of roots. OsHAC1;2 was most abundant in the epidermis, exodermis, outer layer of the cortex, and endodermis cells (Shi et al. 2016). OsHAC4 was expressed in the root epidermis and exodermis (Xu et al. 2017). By overexpression, knocking out, and xylem sap analysis, it was established that they were included in the reduction of arsenate $^{(\mathrm{V})}$ to arsenite $^{(\mathrm{III})}$ and in the efflux of arsenite ${ }^{(\mathrm{III})}$ to the external medium (Shi et al. 2016). Detoxification of the reduced arsenate ${ }^{(\mathrm{V})}$ and the readily available arsenite $^{(\mathrm{III})}$ was maintained by glutathione-based phytochelatins (PCs). Glutathione acts as a precursor for PCs, and its role in arsenic tolerance was corroborated by a study with a sulfur supplement treatment. It was pointed out that most of the arsenate $^{(\mathrm{V})}$ remained in the root, promoting the importance of phytochelatins in binding arsenic (Dixit et al. 2016). The same can be stated for arsenite ${ }^{(\mathrm{III})}$, which complexes with PCs, lowering its mobility from shoot to grain (Duan et al. 2011).

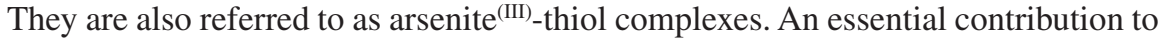
this mechanism was suggested for phytochelatin synthase OsPCS1 and OsPCS2, whereby the former was more expressed in the roots under arsenite ${ }^{(\mathrm{III})}$ treatment and the latter was identified to be an essential isozyme controlling PC synthesis 
(Yamazaki et al. 2018). Arsenite ${ }^{(\mathrm{III})}$-thiol complexes were transported from the cytoplasm into the vacuole by a member of the C-type ATP-binding cassette (ABC) transporter $(O s A B C C)$ family, OsABCCl (Song et al. 2014). In the vacuole, the complexes could be sequestered efficiently since the acidic $\mathrm{pH}$ of 5.5 stabilized them (Ali et al. 2009; Suriyagoda et al. 2018). It was assumed that the same transporters and detoxification mechanisms as in the root cell were used for storing arsenic after relocation, but this is not well investigated yet (Zhao et al. 2010b). Here, the same detoxification mechanism was used again to store arsenic in the vacuole (Suriyagoda et al. 2018). A study with radioactively labeled arsenic during the grain-filling stage showed that arsenite ${ }^{(I I I)}$ was somewhat immobile in the xylem within the rice plant, probably because of its complexation and sequestration (Zhao et al. 2012). The silica pathway might not be used when translocating and unloading arsenite $^{(\mathrm{III})}$ into the grain since silica mainly accumulated in the husk and not in the grain (Norton et al. 2010b). However, the addition of silica decreased inorganic grain arsenic content but increased DMA, by 59\% and 33\%, respectively (Li et al. 2009). In contrast, arsenate ${ }^{(\mathrm{V})}$ was proposed to use the phosphorus pathway throughout the whole transport and translocation (Norton et al. 2010b).

\subsection{The Oxidative Stress Response in Rice}

Concerning metabolism, carbohydrate-, lipid-, protein-, amino acid-, ascorbate-, and aldarate-related pathways were affected by arsenic uptake (Abbas et al. 2018). Membrane transport, cell growth, and death, as well as biodegradation were also altered by showing an up- or down-regulation of gene function (Dubey et al. 2014). When conducting a genome-wide expression study, several gene families were upand down-regulated when grown in arsenite ${ }^{(\mathrm{III})}$, especially facilitating transporters, stress-related genes, regulatory proteins, growth, and development, as well as secondary metabolism. This finding indicated arsenite ${ }^{(\mathrm{III})}$-induced oxidative stress (Chakrabarty et al. 2009). More importantly, arsenic triggers an increased formation of reactive oxygen species (ROS) and therefore not all of them could be scavenged, thus leading to plant damage. Hydrogen peroxide $\left(\mathrm{H}_{2} \mathrm{O}_{2}\right)$ was an ROS that was

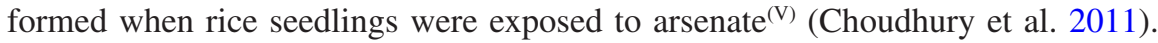
Arsenite $^{(\mathrm{III})}$ was found to promote the development of different ROS, namely, superoxide anion $\left(\mathrm{O}_{2}^{--}\right)$and $\mathrm{H}_{2} \mathrm{O}_{2}$, thus inducing lipid peroxidation in rice seedlings (Mishra et al. 2011). To prevent an excessive amount of $\mathrm{H}_{2} \mathrm{O}_{2}$, seedling roots grown in arsenate $^{(\mathrm{V})}$ solution increased ascorbate peroxidase (APX) activity, which reduced $\mathrm{H}_{2} \mathrm{O}_{2}$ via the ascorbate-glutathione cycle (Dubey et al. 2014). For scavenging the ROS occurring under arsenite ${ }^{(\mathrm{III})}$, the concentrations of enzymatic antioxidants superoxide dismutase (SOD), catalase (CAT), chloroplastic ascorbate peroxidase, guaiacol peroxidase, monodehydroascorbate reductase, and glutathione reductase increased. Higher concentrations of ascorbate and glutathione were found, and the synthesis of phytochelatins and total acid-soluble thiols was enhanced in arsenictreated seedlings (Mishra et al. 2011). Besides ROS, altered RNase and protease 
activity were also an indicator of stress. Their activity was inhibited by the presence of arsenite ${ }^{(\mathrm{III})}$, thus leading to high abundance of RNA and proteins. However, an increase in proline was also reported (Choudhury et al. 2011). Proline is an osmolyte, and its accumulation was usually found under salinity or drought stress (Amini et al. 2015). Under arsenic stress, its abundance led to the assumption that proline could help to protect enzymes in the presence of arsenite ${ }^{(\mathrm{III})}$ (Mishra and Dubey 2006). The same can be reported for heat shock proteins (HSPs), generally formed under a rapid temperature increase, water deficit, or salinity (Ponomarenko et al. 2013). In the presence of arsenic, several HSP genes were upregulated (Chakrabarty et al. 2009).

\subsection{Root Plaque Formation as a Scavenger for Arsenic Stress}

Despite anaerobic conditions in paddy fields, the rhizosphere can be aerobic due to the semiaquatic characteristic of rice forming an aerenchyma when flooded. From there, oxygen is released by the roots, forming an oxidation barrier. This leads to the formation of iron plaque, visible by the reddish coating around the roots, caused by a reoxidation of $\mathrm{Fe}^{(\mathrm{II})}$ to $\mathrm{Fe}^{(\mathrm{III})}$ (Becker and Asch 2005). Iron plaque is mostly composed of lepidocrocite, goethite, and ferrihydrite (Seyfferth et al. 2011). It was proposed that the same reoxidation mechanism and an additional formation of iron plaque would decrease the uptake of arsenic (Lee et al. 2013). This hypothesis could not be confirmed since the proportion of the newly formed $\operatorname{arsenate}^{(\mathrm{V})}$ in a hydroponic solution was very low (Liu et al. 2010). Rice genotypes with a higher radial oxygen loss showed a higher formation of iron plaque. This led to a lower uptake of $\operatorname{arsenate}^{(\mathrm{V})}$ and hence to a lower concentration of total inorganic arsenic in the plant (Wu et al. 2012). However, iron plaque distribution was not homogeneously covering total roots. Indeed, young roots showed little iron plaque formation. Therefore, iron plaque was assumed to be a bulk scavenger for arsenic since it was absent in the main solute-uptake root area (Seyfferth et al. 2011). In general, $\operatorname{arsenate}^{(\mathrm{V})}$ was absorbed more than arsenite ${ }^{(\mathrm{III})}$, and arsenite ${ }^{(\mathrm{III})}$ was desorbed more rapidly (Geng et al. 2017). Surprisingly, the formation of iron plaque enhanced arsenite $^{(\mathrm{III})}$ uptake, but, in this experiment, the iron plaque was formed first and then

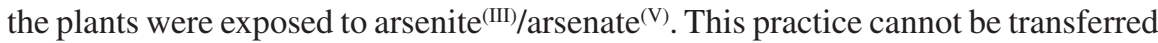
to natural field conditions (Liu et al. 2010). The addition of phosphorus increased the uptake of $\operatorname{arsenate}^{(\mathrm{V})}$ irrespective of iron plaque (Geng et al. 2005; Yang et al. 2020). This could be explained because phosphorus might have occupied the sorption space at the iron plaque, thus releasing more arsenate $\mathrm{a}^{(\mathrm{V})}$.

In conclusion, iron plaque could act as a buffer for arsenate ${ }^{(\mathrm{V})}$ uptake (Liu et al. 2010). Concerning a decreased arsenite ${ }^{(\mathrm{III})}$ uptake, manganese (Mn) plaque was shown to be more effective in capturing arsenite ${ }^{(I I I)}$ than iron plaque as shown by the lower shoot arsenic concentration. However, the control treatment without any plaque formation also showed lower shoot arsenic concentration. Therefore, the role of manganese plaque needs to be further investigated (Liu et al. 2010). In contrast 
to the results identified by hydroponic studies, a microcosm study with a contaminated soil from Bangladesh containing $14 \mathrm{mg}$ As/kg dry weight showed that iron plaque indeed prevented uptake, leading to lower shoot arsenic concentration (Huang et al. 2012b).

\section{State of Knowledge Gaps for Arsenic Accumulation in Rice}

In the past two decades, some progress has been made in understanding the physiological and molecular mechanisms of arsenic metabolism in rice. The regulation and transportation of arsenic from soil to plants are associated with multiple factors: soil texture, water availability, arsenic bioavailability, genotype used, arsenic interactions with other heavy metals and essential minerals, rice ecosystem, microbial interaction, physiological activities, and genotype-by-environment interactions (Norton et al. 2012; Sahoo and Mukherjee 2014) (Fig. 5). Among these factors, the selection of rice cultivars with low-arsenic content in grain and straw is the most efficient and practical approach for decreasing arsenic contamination in rice. The molecular genetic mechanisms of arsenic accumulation in the root, shoot, and grain need to be understood clearly for designing efficient breeding strategies and developing elite breeding materials, which combine arsenic tolerance, low-arsenic uptake, and high-grain yield.

Several experiments were conducted to understand the physiological mechanisms underlying rice varieties accumulating low arsenic (Norton et al. 2012; Murugaiyan et al. 2019). However, some of them show inconsistency and methodological errors, leading to wrong assumptions. Many studies focused on arsenate ${ }^{(\mathrm{V})}$ rather than arsenite ${ }^{(I I I)}$ although arsenite ${ }^{(I I I)}$ is the predominant form in paddy soils, where the majority of rice is produced. Abedin et al. (2002a) were the first to elu-

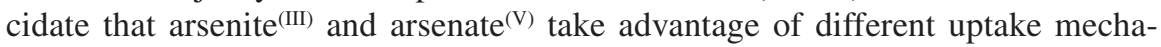
nisms in rice. After this finding, the focus should have been more toward elevated arsenite $^{(\mathrm{III})}$ concentrations in rice experiments, which was not the case. When identifying the AsTol QTL on chromosome 6, 1 ppm of arsenate ${ }^{(\mathrm{V})}$ was used (Dasgupta et al. 2004). When investigating the accumulation in widely used cultivars in Bangladesh, the soil was obtained from the Bangladesh Rice Research Institute (BRRI) and enriched with arsenate ${ }^{(\mathrm{V})}$ rather than arsenite $^{(\mathrm{III})}$. There, they found that a hybrid variety accumulated the most arsenic in the straw at a treatment of $30 \mathrm{mg}$ As $/ \mathrm{kg}$, using $\mathrm{Na}_{2} \mathrm{HAsO}_{4} \cdot 7 \mathrm{H}_{2} \mathrm{O}$. It was stated that the hybrid variety would show a higher phytotoxicity and accumulation ability (Rahman et al. 2007). This finding needs to be proven when the soil is enriched with arsenite ${ }^{(\mathrm{III})}$ because, otherwise, the hybrid could contain a more efficient phosphorus-uptake pathway, which $\operatorname{arsenate}^{(\mathrm{V})}$ took advantage of. When estimating the grain arsenic content determined in different soil arsenic concentrations, arsenate ${ }^{(\mathrm{V})}$ was used to enrich the soil (Rahman et al. 2008). It cannot be clearly stated how important the difference between using arsenate ${ }^{(\mathrm{V})}$ and arsenite ${ }^{(\mathrm{III})}$ really is unless both forms are tested in the same experiment. Another shortcoming, especially when finding QTLs, is 
when a low-arsenic concentration is used. The concentration in the experiment should simulate field conditions with typical concentrations of $4-8 \mathrm{mg} / \mathrm{kg}$. Therefore, a concentration of less than $1 \mathrm{ppm}$ cannot lead to reliable results (Abedin et al. 2002a; Norton et al. 2010a). Most of the published studies related to arsenic uptake and accumulation were carried out in a hydroponics system or pot culture, and these experiments need to be carried out in a contaminated field for better understanding.

Rice production in the major rice-growing countries is shifting toward more efficient technologies such as direct-seeded rice (DSR) and alternate wetting and drying (AWD) (Pathak et al. 2011; Richards and Sander 2014). It is essential to identify suitable genotypes, genes, and QTLs associated with overcoming arsenic contamination under these technologies. The presence of flooded water influences arsenic speciation. It is crucial to use arsenate ${ }^{(\mathrm{V})}$ for conducting experiments related to dryDSR conditions and arsenite ${ }^{(\mathrm{III})}$ for wet-DSR conditions. So far, no experiment has been conducted to observe the germination ability of rice under DSR conditions in contaminated soils. AWD technology was proposed to decrease arsenic content in rice. However, no studies have been conducted to observe how arsenic species acted when applying AWD technology. Since arsenic translocation from soil depends on flooding, it is understood that, during the wetting period, arsenite ${ }^{(I I I)}$ dominates, and, during the drying period, arsenate ${ }^{(\mathrm{V})}$ dominates. However, no data were available to validate this observation.

\section{Possible Mitigation Strategies for Arsenic Accumulation in Rice}

Several novel methodologies in rice cooking provided promising results for a decrease in arsenic content by using a continual flow of clean water over the raw rice before cooking (Carey et al. 2015). Carey et al. (2015) stated that about $85 \%$ of the inorganic arsenic was removed from the raw rice by using a continual flow of clean cooking water. Several researchers also found that using a higher water-to-rice ratio for cooking, followed by removal of the extra water (starch), significantly decreased the arsenic in cooked rice (Sengupta et al. 2006; Stanton et al. 2015). For instance, Sengupta et al. (2006) reported a decrease in arsenic by $57 \%$ by washing the rice grain several times until the water looks transparent/clear, and a cooking process with a 6:1 ratio of water to rice grain with draining of the excess water. However, the effect of this procedure on the content of essential water-soluble nutrients such as minerals or B-vitamins remains to be elucidated.

Selection of existing rice cultivars that are biologically restricted in terms of arsenic accumulation in the grain offers great potential for use in breeding programs, as some rice cultivars can accumulate 20-30-fold less arsenic than others (Murugaiyan et al. 2019). The physiological pathways and molecular genetics of arsenic accumulation in rice were linked to many QTLs and genes involved in the uptake and translocation of arsenic in rice (Dasgupta et al. 2004; Tuli et al. 2010). 
Still, a gap exists in identifying the candidate genes and allelic variants of the genes governing low-arsenic content in rice grain. Using recent trends of allele mining and haplotype breeding technologies can help to limit arsenic accumulation in the grain, which is a prerequisite for breeding programs to develop low-arsenic-accumulating rice cultivars (Murugaiyan et al. 2019). Hence, several strategies are possible to decrease arsenic in rice grains, including the following:

1. Mitigation strategies related to rice cooking can help to decrease arsenic content in the major staple food crop, rice. The ratio of rice grain for cooking, the amount of water used for washing, cooking vessels, and duration of the cooking process can decrease the arsenic in cooked rice (Carey et al. 2015).

2. Supplementation of mineral nutrient elements such as S, P, Fe, and Si can also significantly diminish the accumulation of arsenic content in rice grain by minimizing its uptake and transport in food crops. For instance, $\mathrm{P}$ and $\mathrm{Si}$ are complementary in nature to arsenic in competing for uptake. Therefore, the external application of these mineral nutrients decreases the chances of arsenic uptake from the soil (Alkorta et al. 2004; Jian et al. 2008).

3. Water-saving technologies such as direct-seeded rice cultivation are viable, immediate, and sustainable solutions for decreasing arsenic content in rice $\mathrm{Hu}$ et al. 2013; Abedin et al. 2002a). Talukder et al. (2011) reported that arsenic uptake in rice plants $(0.23-0.26 \mathrm{mg} / \mathrm{kg})$ is lower with aerobic water management than in anaerobic rice cultivation $(0.60-0.67 \mathrm{mg} / \mathrm{kg})$.

4. The identification of donors/selection of rice cultivars with low arsenic can minimize the risk of arsenic associated with human diseases and be eco-friendly to nature (Norton et al. 2012).

5. The development of breeding lines through the introgression of QTLs and genes for low arsenic into elite rice cultivars can ensure high-grain yield and lowarsenic content in cultivars suitable for cultivation in arsenic-contaminated soils (Murugaiyan et al. 2019).

6. CRISPR/Cas9-based genome-editing tools can be useful for modifying crucialregulated genes (OsPht1:8, Lsi 1, OsNRAMP1, and OsABCC1) for the interruption or modification of genes that regulate pathways contributing to low-arsenic accumulation in rice grain. Targeting the genes involved in the phloem transport mechanism and nodes could be crucial for transporting to rice grain (Song et al. 2014). Thus, identifying phloem-localized transporters and their manipulation will provide a promising approach toward decreasing arsenic accumulation in grain.

\section{Future Directions and Conclusions}

The nature of arsenic being redox-active, highly toxic to organisms, and its tendency to be methylated make it a complex and important mineral to study. Arsenic uptake and metabolism in rice need to be placed in the broader context of 
biogeochemical cycling of arsenic in the environment. Bioavailability and speciation of arsenic in the soil are strongly dependent on environmental conditions, and this knowledge is crucial as it determines the extent of arsenic accumulation by rice and the consequences of arsenic contamination in the food chain. The widespread arsenic contamination in the environment, the mobilization of arsenic into rice grain even in soils with baseline arsenic concentrations, and the realization that excessive arsenic accumulation in rice can present a health risk to humans have provided a recent impetus in research on this subject. Therefore, significant progress has been made in recent years to understand arsenic uptake, speciation, and detoxification in plants. However, substantial knowledge gaps exist on the mechanisms of arsenic sequestration in the vacuoles and for arsenic loading and unloading in xylem and phloem. Still, there is a need to understand the regulation of arsenic accumulation in grain and to unravel the pathways and enzymes responsible for arsenate ${ }^{(\mathrm{V})}$ reduction and methylation. Recent advances in the analytical techniques for arsenic speciation are instrumental in enhancing our understanding of arsenic biogeochemical cycling and plant metabolism. Combining these analytical tools with molecular genetics and functional genomics should provide ample opportunities for unraveling the mechanisms of arsenic transport, metabolism, and regulation.

\section{References}

Abbas G, Murtaza B, Bibi I et al (2018) Arsenic uptake, toxicity, detoxification, and speciation in plants: physiological, biochemical, and molecular aspects. Int J Environ Res Public Health 15:59. https://doi.org/10.3390/ijerph15010059

Abedin MJ, Cotter-Howells J, Meharg AA (2002a) Arsenic uptake and accumulation in rice (Oryza sativa L.) irrigated with contaminated water. Plant Soil 240:311-319. https://doi.org/1 0.1023/A:1015792723288

Abedin MJ, Cresser MS, Meharg AA et al (2002b) Arsenic accumulation and metabolism in rice (Oryza sativa L.). Environ Sci Technol 36:962-968. https://doi.org/10.1021/es0101678

Abedin MJ, Feldmann J, Meharg AA (2002c) Uptake kinetics of arsenic species in rice plants. Plant Physiol 128:1120-1128. https://doi.org/10.1104/pp.010733

Abernathy C, Chakraborti D, Edmonds JS et al (2001) Environmental health criteria for arsenic and arsenic compounds. Environ health criteria 224. WHO, Geneva

Ali W, Isayenkov SV, Zhao FJ, Maathuis FJM (2009) Arsenite transport in plants. Cell Mol Life Sci 66:2329-2339. https://doi.org/10.1007/s00018-009-0021-7

Ali J, Aslam UM, Tariq R et al (2018a) Exploiting the genomic diversity of rice (Oryza sativa L.): SNP-typing in 11 early-backcross introgression-breeding populations. Front Plant Sci 9:849. https://doi.org/10.3389/fpls.2018.00849

Ali J, Jewel ZA, Mahender A et al (2018b) Molecular genetics and breeding for nutrient use efficiency in rice. Int J Mol Sci 19:1762. https://doi.org/10.3390/ijms19061762

Alkorta I, Hernández-Allica J, Becerril JM et al (2004) Recent findings on the phytoremediation of soils contaminated with environmentally toxic heavy metals and metalloids such as zinc, cadmium, lead, and arsenic. Rev Environ Sci Biotechnol 3:71-90. https://doi.org/10.1023/B:RES B.0000040059.70899.3d

Amini M, Abbaspour KC, Berg M et al (2008) Statistical modeling of global geogenic arsenic contamination in groundwater. Environ Sci Technol 42:3669-3675. https://doi.org/10.1021/ es702859e

Amini S, Ghobadi C, Yamchi A (2015) Proline accumulation and osmotic stress: an overview of P5CS gene in plants. Genet Agric Biotechnol Inst Tabarestan 3:44-55 
Anawar HM, Akai J, Komaki K et al (2003) Geochemical occurrence of arsenic in groundwater of Bangladesh: sources and mobilization processes. J Geochem Explor 77:109-131. https://doi. org/10.1016/S0375-6742(02)00273-X

Ashikari M, Ma JF (2015) Exploring the power of plants to overcome environmental stresses. Rice 8:10. https://doi.org/10.1186/s12284-014-0037-y

Becker M, Asch F (2005) Iron toxicity in rice:conditions and management concepts. J Plant Nutr Soil Sci 168:558-573

Begum M, Mondal S (2019) Relative toxicity of arsenite and arsenate on early seedling growth and photosynthetic pigments of rice. Curr J Appl Sci Technol 33:1-5. https://doi.org/10.9734/ cjast $/ 2019 / \mathrm{v} 33 \mathrm{i} 430087$

Bewley JD (1997) Seed germination and dormancy. Plant Cell 9:1055-1066. https://doi. org/10.1105/tpc.9.7.1055

Bhattacharya P, Samal AC, Majumdar J, Santra SC (2010) Accumulation of arsenic and its distribution in rice plant (Oryza sativa L.) in Gangetic West Bengal, India. Paddy Water Environ 8:63-70. https://doi.org/10.1007/s10333-009-0180-z

Bondu R, Cloutier V, Rosa E, Benzaazoua M (2016) A review and evaluation of the impacts of climate change on geogenic arsenic in groundwater from fractured bedrock aquifers. Water Air Soil Pollut 227:296. https://doi.org/10.1007/s11270-016-2936-6

Brammer H, Ravenscroft P (2009) Arsenic in groundwater: a threat to sustainable agriculture in South and South-east Asia. Environ Int 35:647-654. https://doi.org/10.1016/j. envint.2008.10.004

Caldwell BK, Caldwell JC, Mitra SN, Smith W (2003) Searching for an optimum solution to the Bangladesh arsenic crisis. Soc Sci Med 56:2089-2096. https://doi.org/10.1016/ S0277-9536(02)00203-4

Carbonell-Barrachina Á, Munera-Picazo S, Cano-Lamadrid M et al (2015) Arsenic in your food: potential health hazards from arsenic found in rice. Nutr Diet Suppl 7:1. https://doi. org/10.2147/nds.s52027

Carey AM, Scheckel KG, Lombi E et al (2010) Grain unloading of arsenic species in rice. Plant Physiol 152:309-319. https://doi.org/10.1104/pp.109.146126

Carey M, Jiujin X, Farias JG, Meharg AA (2015) Rethinking rice preparation for highly efficient removal of inorganic arsenic using percolating cooking water. PLoS One 10:e0131608. https:// doi.org/10.1371/journal.pone. 0131608

Chakrabarty D, Trivedi PK, Misra P et al (2009) Comparative transcriptome analysis of arsenate and arsenite stresses in rice seedlings. Chemosphere 74:688-702. https://doi.org/10.1016/j. chemosphere.2008.09.082

Chakraborti D, Rahman MM, Das B et al (2013) Groundwater arsenic contamination in GangaMeghna-Brahmaputra plain, its health effects and an approach for mitigation. Environ Earth Sci 70:1993-2008. https://doi.org/10.1007/s12665-013-2699-y

Chao DY, Chen Y, Chen J et al (2014) Genome-wide association mapping identifies a new arsenate reductase enzyme critical for limiting arsenic accumulation in plants. PLoS Biol 12:e1002009. https://doi.org/10.1371/journal.pbio.1002009

Chen WQ, Shi YL, Wu SL, Zhu YG (2016) Anthropogenic arsenic cycles: a research framework and features. J Clean Prod 139:328-336. https://doi.org/10.1016/j.jclepro.2016.08.050

Chen Y, Sun SK, Tang Z et al (2017) The nodulin 26-like intrinsic membrane protein OsNIP3;2 is involved in arsenite uptake by lateral roots in rice. J Exp Bot 68:3007-3016. https://doi. org/10.1093/jxb/erx 165

Choudhury B, Chowdhury S, Biswas AK (2011) Regulation of growth and metabolism in rice (Oryza sativa L.) by arsenic and its possible reversal by phosphate. J Plant Interact 6:15-24. https://doi.org/10.1080/17429140903487552

Clemens S (2006) Toxic metal accumulation, responses to exposure and mechanisms of tolerance in plants. Biochimie 88:1707-1719

Clemens S, Ma JF (2016) Toxic heavy metal and metalloid accumulation in crop plants and foods. Annu Rev Plant Biol 67:489-512. https://doi.org/10.1146/annurev-arplant-043015-112301 
Das B, Nayak B, Pal A et al (2008) Groundwater arsenic contamination and its health effects in the Ganga-Meghna-Brahmaputra plain. In: Groundwater for sustainable development: problems, perspectives and challenges. Routledge, London, pp 257-269

Das I, Ghosh K, Das DK, Sanya SK (2013) Assessment of arsenic toxicity in rice plants in areas of West Bengal. Chem Speciat Bioavailab 25:201-208. https://doi.org/10.318 4/095422913X13785717162124

Dasgupta T, Hossain SA, Meharg AA, Price AH (2004) An arsenate tolerance gene on chromosome 6 of rice. New Phytol 163:45-49. https://doi.org/10.1111/j.1469-8137.2004.01109.x

Dixit G, Singh AP, Kumar A et al (2016) Reduced arsenic accumulation in rice (Oryza sativa L.) shoot involves sulfur-mediated improved thiol metabolism, antioxidant system and altered arsenic transporters. Plant Physiol Biochem 99:86-96. https://doi.org/10.1016/j. plaphy.2015.11.005

Dobermann A, Fairhurst T (2000) Rice: nutrient disorders \& nutrient management. http://books. irri.org/9810427425_content.pdf

Duan GL, Hu Y, Liu WJ et al (2011) Evidence for a role of phytochelatins in regulating arsenic accumulation in rice grain. Environ Exp Bot 71:416-421. https://doi.org/10.1016/j. envexpbot.2011.02.016

Duan G, Shao G, Tang Z et al (2017) Genotypic and environmental variations in grain cadmium and arsenic concentrations among a panel of high-yielding rice cultivars. Rice 10:9. https://doi. org/10.1186/s12284-017-0149-2

Dubey S, Shri M, Misra P et al (2014) Heavy metals induce oxidative stress and genome-wide modulation in transcriptome of rice root. Funct Integr Genom 14:401-417. https://doi. org/10.1007/s10142-014-0361-8

Duker AA, Carranza EJM, Hale M (2005) Arsenic geochemistry and health. Environ Int 31:631-641

Finnegan PM, Chen W (2012) Arsenic toxicity: the effects on plant metabolism. Front Physiol 3:182. https://doi.org/10.3389/fphys.2012.00182

Flora SJS, Pachauri V, Saxena G (2011) Arsenic, cadmium and lead. In: Reproductive and developmental toxicology. Elsevier, Amsterdam, pp 415-438

Frei M, Becker K (2005) Integrated rice-fish culture: coupled production saves resources. Nat Resour Forum 29:135-143. https://doi.org/10.1111/j.1477-8947.2005.00122.x

Gao JP, Chao DY, Lin HX (2007) Understanding abiotic stress tolerance mechanisms: recent studies on stress response in rice. J Integr Plant Biol 49:742-750

Garai R, Chakraborty AK, Dey SB, Saha KC (1984) Chronic arsenic poisoning from tube-well water. J Indian Med Assoc 82:34-35

Geng CN, Zhu YG, Liu WJ, Smith SE (2005) Arsenate uptake and translocation in seedlings of two genotypes of rice is affected by external phosphate concentrations. Aquat Bot 83:321-331. https://doi.org/10.1016/j.aquabot.2005.07.003

Geng A, Wang X, Wu L et al (2017) Arsenic accumulation and speciation in rice grown in arsanilic acid-elevated paddy soil. Ecotoxicol Environ Saf 137:172-178. https://doi.org/10.1016/j. ecoenv.2016.11.030

Gorny J, Billon G, Lesven L et al (2015) Arsenic behavior in river sediments under redox gradient: a review. Sci Total Environ 505:423-434. https://doi.org/10.1016/j.scitotenv.2014.10.011

GRiSP (Global Rice Science Partnership) (2013) Rice almanac, 4th edn. International Rice Research Institute, Los Baños. 283 p

Guha Mazumder DN (2008) Chronic arsenic toxicity \& human health. Indian J Med Res $128: 436-447$

Guha Mazumder DN (2015) Health effects of chronic arsenic toxicity. In: Handbook of arsenic toxicology. Elsevier, Amsterdam, pp 137-177

Hayashi S, Kuramata M, Abe T et al (2017) Phytochelatin synthase OsPCS1 plays a crucial role in reducing arsenic levels in rice grains. Plant J 91:840-848. https://doi.org/10.1111/tpj.13612

He D, Yang P (2013) Proteomics of rice seed germination. Front Plant Sci 4:246 
Hossain MF (2006) Arsenic contamination in Bangladesh:an overview. Agric Ecosyst Environ 113:1-16. https://doi.org/10.1016/j.agee.2005.08.034

Hu P, Huang J, Ouyang Y et al (2013) Water management affects arsenic and cadmium accumulation in different rice cultivars. Environ Geochem Health 35:767-778. https://doi.org/10.1007/ s10653-013-9533-z

Huang X, Kurata N, Wei X et al (2012a) A map of rice genome variation reveals the origin of cultivated rice. Nature 490:497-501. https://doi.org/10.1038/nature11532

Huang Y, Chen Z, Liu W (2012b) Influence of iron plaque and cultivars on antimony uptake by and translocation in rice (Oryza sativa L.) seedlings exposed to $\mathrm{Sb}^{(\mathrm{III})}$ or $\mathrm{Sb}^{(\mathrm{V})}$. Plant Soil 352:41-49. https://doi.org/10.1007/s11104-011-0973-x

Islam S, Rahman MM, Islam MR, Naidu R (2016) Arsenic accumulation in rice: consequences of rice genotypes and management practices to reduce human health risk. Environ Int 96:139-155. https://doi.org/10.1016/j.envint.2016.09.006

Järup L (2003) Hazards of heavy metal contamination. Br Med Bull 68:167-182

Jia Y, Huang H, Zhong M et al (2013) Microbial arsenic methylation in soil and rice rhizosphere. Environ Sci Technol 47:3141-3148. https://doi.org/10.1021/es303649v

Jian FM, Yamaji N, Mitani N et al (2008) Transporters of arsenite in rice and their role in arsenic accumulation in rice grain. Proc Natl Acad Sci U S A 105:9931-9935. https://doi.org/10.1073/ pnas.0802361105

Jiang JQ, Ashekuzzaman SM, Jiang A et al (2013) Arsenic-contaminated groundwater and its treatment options in Bangladesh. Int J Environ Res Public Health 10:18-46. https://doi. org/10.3390/ijerph10010018

Jomova K, Valko M (2011) Advances in metal-induced oxidative stress and human disease. Toxicology 283:65-87

Kalia K, Flora SJS (2005) Strategies for safe and effective therapeutic measures for chronic arsenic and lead poisoning. J Occup Health 47:1-21

Kamiya T, Islam MR, Duan G et al (2013) Phosphate deficiency signaling pathway is a target of arsenate and phosphate transporter $O S P T 1$ is involved in As accumulation in shoots of rice. Soil Sci Plant Nutr 59:580-590. https://doi.org/10.1080/00380768.2013.804390

Khush GS (1997) Origin, dispersal, cultivation and variation of rice. Plant Mol Biol 35:25-34

Kumar M, Puri A (2012) A review of permissible limits of drinking water. Indian J Occup Environ Med 16:40-44. https://doi.org/10.4103/0019-5278.99696

Kuramata M, Abe T, Kawasaki A et al (2013) Genetic diversity of arsenic accumulation in rice and QTL analysis of methylated arsenic in rice grains. Rice 6:1-10. https://doi.org/10.1186/193 9-8433-6-3

Laha M (2017) Irrigation and groundwater hazards in India. Trans Inst Indian Geogr 39:237-252

Lawson M, Polya DA, Boyce AJ et al (2016) Tracing organic matter composition and distribution and its role on arsenic release in shallow Cambodian groundwaters. Geochim Cosmochim Acta 178:160-177. https://doi.org/10.1016/j.gca.2016.01.010

Lee JJ, Jang CS, Wang SW et al (2008) Delineation of spatial redox zones using discriminant analysis and geochemical modelling in arsenic-affected alluvial aquifers. Hydrol Process 22:3029-3041. https://doi.org/10.1002/hyp.6884

Lee CH, Hsieh YC, Lin TH, Lee DY (2013) Iron plaque formation and its effect on arsenic uptake by different genotypes of paddy rice. Plant Soil 363:231-241. https://doi.org/10.1007/ s11104-012-1308-2

Li Z, Ali J (2017) Breeding green super rice (GSR) varieties for sustainable rice cultivation. In: Sasaki T (ed) Achieving sustainable cultivation of rice, vol 1. Burleigh Dodds Science Publishing, Cambridge, pp 109-130

Li RY, Stroud JL, Ma JF et al (2009) Mitigation of arsenic accumulation in rice with water management and silicon fertilization. Environ Sci Technol 43:3778-3783. https://doi.org/10.1021/ es $803643 \mathrm{v}$

Li G, Sun GX, Williams PN et al (2011) Inorganic arsenic in Chinese food and its cancer risk. Environ Int 37:1219-1225. https://doi.org/10.1016/j.envint.2011.05.007 
Liu J, Cao C, Wong M et al (2010) Variations between rice cultivars in iron and manganese plaque on roots and the relation with plant cadmium uptake. J Environ Sci 22:1067-1072. https://doi. org/10.1016/S1001-0742(09)60218-7

Liu X, Chen S, Chen M et al (2019) Association study reveals genetic loci responsible for arsenic, cadmium and lead accumulation in rice grain in contaminated farmlands. Front Plant Sci 10:61. https://doi.org/10.3389/fpls.2019.00061

Lomax C, Liu WJ, Wu L et al (2012) Methylated arsenic species in plants originate from soil microorganisms. New Phytol 193:665-672. https://doi.org/10.1111/j.1469-8137.2011.03956.x

Lou LQ, Ye ZH, Wong MH (2009) A comparison of arsenic tolerance, uptake and accumulation between arsenic hyperaccumulator, Pteris vittata L. and non-accumulator, P. semipinnata L.: a hydroponic study. J Hazard Mater 171:436-442. https://doi.org/10.1016/j.jhazmat.2009.06.020

Ma J, Takahashi E (1990) Effect of silicon on the growth and phosphorus uptake of rice. Plant Soil 126:115. https://doi.org/10.1007/BF00041376

Maclean J, Dawe DC, Hardy B, Hettel G (eds) (2002) Rice almanac, 3rd edn. International Rice Research Institute, Los Baños

Mandal BK, Suzuki KT (2002) Arsenic round the world: a review. Talanta 58:201-235. https://doi. org/10.1016/S0039-9140(02)00268-0

Mazumder DNG (2003) Chronic arsenic toxicity: clinical features, epidemiology, and treatment: experience in West Bengal. J Environ Sci Health Part A Toxic Hazardous Subst Environ Eng 38:141-163. https://doi.org/10.1081/ESE-120016886

Meharg AA, Hartley-Whitaker J (2002)Arsenic uptake and metabolismin arsenic-resistant and nonresistant plant species. New Phytol 154:29-43. https://doi.org/10.1046/j.1469-8137.2002.00363.x

Meharg AA, Rahman M (2003) Arsenic contamination of Bangladesh paddy field soils: implications for rice contribution to arsenic consumption. Environ Sci Technol 37:229-234. https:// doi.org/10.1021/es0259842

Messerschmidt M, Wagner A, Wong MW, Luger P (2002) Atomic properties of N2O4 based on its experimental charge density. J Am Chem Soc 124:732-733. https://doi.org/10.1021/ja011802c

Mishra S, Dubey RS (2006) Inhibition of ribonuclease and protease activities in arsenic exposed rice seedlings: role of proline as enzyme protectant. J Plant Physiol 163:927-936. https://doi. org/10.1016/j.jplph.2005.08.003

Mishra S, Jha AB, Dubey RS (2011) Arsenite treatment induces oxidative stress, upregulates antioxidant system, and causes phytochelatin synthesis in rice seedlings. Protoplasma 248:565-577. https://doi.org/10.1007/s00709-010-0210-0

Mochizuki H (2019) Arsenic neurotoxicity in humans. Int J Mol Sci 20:3418. https://doi. org/10.3390/ijms20143418

Mohan D, Pittman CU (2007) Arsenic removal from water/wastewater using adsorbents: a critical review. J Hazard Mater 142:1-53. https://doi.org/10.1016/j.jhazmat.2007.01.006

Molden D (2013) Water for food, water for life: a comprehensive assessment of water management in agriculture. Routledge, London

Molina J, Sikora M, Garud N et al (2011) Molecular evidence for a single evolutionary origin of domesticated rice. Proc Natl Acad Sci U S A 108:8351-8356. https://doi.org/10.1073/ pnas. 1104686108

Mosa KA, Kumar K, Chhikara S et al (2012) Members of rice plasma membrane intrinsic proteins subfamily are involved in arsenite permeability and tolerance in plants. Transgenic Res 21:1265-1277. https://doi.org/10.1007/s11248-012-9600-8

Muhammad S, Tahir Shah M, Khan S (2010) Arsenic health risk assessment in drinking water and source apportionment using multivariate statistical techniques in Kohistan region, northern Pakistan. Food Chem Toxicol 48:2855-2864. https://doi.org/10.1016/j.fct.2010.07.018

Mukherjee A, Kundu M, Basu B et al (2017) Arsenic load in rice ecosystem and its mitigation through deficit irrigation. J Environ Manag 197:89-95. https://doi.org/10.1016/j. jenvman.2017.03.037

Murugaiyan V (2019) Genetic mapping of quantitative trait loci associated with arsenic tolerance and accumulation in rice (Oryza sativa L.). Universitäts- und Landesbibliothek, Bonn 
Murugaiyan V, Ali J, Mahender A et al (2019) Mapping of genomic regions associated with arsenic toxicity stress in a backcross-breeding populations of rice (Oryza sativa L.). Rice 12:61. https://doi.org/10.1186/s12284-019-0321-y

Muthayya S, Sugimoto JD, Montgomery S, Maberly GF (2014) An overview of global rice production, supply, trade, and consumption. Ann N Y Acad Sci 1324:7-14. https://doi.org/10.1111/ nyas. 12540

National Research Council (US) Committee on Medical and Biological Effects of Environmental Pollutants (1977) Distribution of arsenic in the environment. In: Arsenic: medical and biologic effects of environmental pollutants. National Academies Press, Washington, DC, p 3

Ng JC (2005) Environmental contamination of arsenic and its toxicological impact on humans. Environ Chem 2:146-160

Nickson RT, Mcarthur JM, Ravenscroft P et al (2000) Mechanism of arsenic release to groundwater, Bangladesh and West Bengal. Appl Geochem 15:403-413. https://doi.org/10.1016/ S0883-2927(99)00086-4

Nordberg GF, Jin T, Hong F et al (2005) Biomarkers of cadmium and arsenic interactions. Toxicol Appl Pharmacol 206:191-197. https://doi.org/10.1016/j.taap.2004.11.028

Norton GJ, Deacon CM, Xiong L et al (2010a) Genetic mapping of the rice ionome in leaves and grain: identification of QTLs for 17 elements including arsenic, cadmium, iron and selenium. Plant Soil 329:139-153. https://doi.org/10.1007/s11104-009-0141-8

Norton GJ, Islam MR, Duan G et al (2010b) Arsenic shoot-grain relationships in field grown rice cultivars. Environ Sci Technol 44:1471-1477. https://doi.org/10.1021/es902992d

Norton GJ, Pinson SRM, Alexander J et al (2012) Variation in grain arsenic assessed in a diverse panel of rice (Oryza sativa) grown in multiple sites. New Phytol 193:650-664. https://doi. org/10.1111/j.1469-8137.2011.03983.x

Norton GJ, Douglas A, Lahner B, Yakubova E, Guerinot ML, et al (2014) Genome wide association mapping of grain arsenic, copper, molybdenum and zinc in rice (Oryza sativa L.) grown at four international field sites. PLoS One 9(2): e89685. https://doi.org/10.1371/journal.pone.0089685

Norton GJ, Travis AJ, Talukdar P et al (2019) Genetic loci-regulating arsenic content in rice grains when grown flooded or under alternative wetting and drying irrigation. Rice 12:54. https://doi. org/10.1186/s12284-019-0307-9

Nriagu JO, Bhattacharya P, Mukherjee AB et al (2007) Arsenic in soil and groundwater: an overview. In: Trace metals and other contaminants in the environment. Elsevier, Amsterdam, pp 3-60

O'Day PA (2006) Chemistry and mineralogy of arsenic. Elements 2:77-83. https://doi.org/10.2113/ gselements.2.2.77

Pandey S, Rai R, Rai LC (2015) Biochemical and molecular basis of arsenic toxicity and tolerance in microbes and plants. In: Handbook of arsenic toxicology. Elsevier, Amsterdam, pp 627-674

Pathak H, Tewari A, Sankhyan S et al (2011) Direct-seeded rice: potential, performance and problems: a review. Curr Adv Agric Sci Int 3:77

Pohl HR, Roney N, Abadin HG (2011) Metal ions affecting the neurological system. Met Ions Life Sci 8:247-262

Ponomarenko M, Stepanenko I, Kolchanov N (2013) Heat shock proteins. In: Brenner's encyclopedia of genetics, 2nd edn. Elsevier, Amsterdam, pp 402-405

Rahman MA, Hasegawa H, Rahman MM et al (2007) Arsenic accumulation in rice (Oryza sativa L.) varieties of Bangladesh: a glass house study. Water Air Soil Pollut 185:53-61. https://doi. org/10.1007/s11270-007-9425-x

Rahman MA, Hasegawa H, Rahman MM et al (2008) Straighthead disease of rice (Oryza sativa L.) induced by arsenic toxicity. Environ Exp Bot 62:54-59. https://doi.org/10.1016/j. envexpbot.2007.07.016

Rajjou L, Duval M, Gallardo K et al (2012) Seed germination and vigor. Annu Rev Plant Biol 63:507-533

Rao KP, Vani G, Kumar K et al (2011) Arsenic stress activates MAP kinase in rice roots and leaves. Arch Biochem Biophys 506:73-82. https://doi.org/10.1016/j.abb.2010.11.006

Rao CS, Lal R, Prasad JVNS et al (2015) Potential and challenges of rainfed farming in India. Adv Agron 133:113-181 
Richards M, Sander BO (2014) Alternate wetting and drying in irrigated rice. J AHIMA. https:// doi.org/10.1016/j.techfore.2006.05.021

Ronzan M, Piacentini D, Fattorini L et al (2018) Cadmium and arsenic affect root development in Oryza sativa L. negatively interacting with auxin. Environ Exp Bot 151:64-75. https://doi. org/10.1016/j.envexpbot.2018.04.008

Roy P, Saha A (2002) Metabolism and toxicity of arsenic: a human carcinogen. Curr Sci 82:38-45

Safiuddin M, Shirazi SM, Yussof S (2011) Arsenic contamination of groundwater in Bangladesh: a review. Int J Phys Sci 6:6791-6800. https://doi.org/10.5897/IJPS11.1300

Sahoo PK, Mukherjee A (2014) Arsenic fate and transport in the groundwater-soil-plant system: an understanding of suitable rice paddy cultivation in arsenic-enriched areas. In: Recent trends in modelling of environmental contaminants. Springer, New Delhi, pp 21-44

Sayan B, Kaushik G, Sushanta D et al (2012) Arsenic bioaccumulation in rice and edible plants and subsequent transmission through food chain in Bengal basin: a review of the perspectives for environmental health. Toxicol Environ Chem 94:429

Seneviratne M, Rajakaruna N, Rizwan M et al (2019) Heavy metal-induced oxidative stress on seed germination and seedling development: a critical review. Environ Geochem Health 41:1813-1831. https://doi.org/10.1007/s10653-017-0005-8

Sengupta M, Bishayi B (2002) Effect of lead and arsenic on murine macrophage response. Drug Chem Toxicol 25:459-472

Sengupta MK, Hossain MA, Mukherjee A et al (2006) Arsenic burden of cooked rice: traditional and modern methods. Food Chem Toxicol 44:1823-1829. https://doi.org/10.1016/j. fct.2006.06.003

Seyfferth AL, Webb SM, Andrews JC, Fendorf S (2011) Defining the distribution of arsenic species and plant nutrients in rice (Oryza sativa L.) from the root to the grain. Geochim Cosmochim Acta 75:6655-6671. https://doi.org/10.1016/j.gca.2011.06.029

Shah AL, Naher UA, Hasan Z et al (2014) Influence of arsenic on rice growth and its mitigation with different water management techniques. Asian J Crop Sci 6:373-382. https://doi. org/10.3923/ajcs.2014.373.382

Shaibur MR, Kitajima N, Sugawara R et al (2006) Physiological and mineralogical properties of arsenic-induced chlorosis in rice seedlings grown hydroponically. Soil Sci Plant Nutr 52:691-700. https://doi.org/10.1111/j.1747-0765.2006.00085.x

Shepherd K, Hubbard D, Fenton N et al (2015) Policy: development goals should enable decisionmaking. Nature 523:152-154. https://doi.org/10.1038/523152a

Shi S, Wang T, Chen $\mathrm{Z}$ et al (2016) OsHAC1;1 and OsHAC1;2 function as arsenate reductases and regulate arsenic accumulation. Plant Physiol 172:1708-1719. https://doi.org/10.1104/ pp.16.01332

Smith AH, Lingas EO, Rahman M (2000) Contamination of drinking-water by arsenic in Bangladesh: a public health emergency. Bull World Health Organ 78:1093-1103. https://doi. org/10.1590/S0042-96862000000900005

Song WY, Yamaki T, Yamaji N et al (2014) A rice ABC transporter, OsABCC1, reduces arsenic accumulation in the grain. Proc Natl Acad Sci U S A 111:15699-15704. https://doi. org/10.1073/pnas.1414968111

Stanton BA, Caldwell K, Congdon CB et al (2015) MDI Biological Laboratory Arsenic Summit: approaches to limiting human exposure to arsenic. Curr Environ Health Rep 2:329-337. https:// doi.org/10.1007/s40572-015-0057-9

Sturchio E, Zanellato M, Minoia C, Bemporad E (2013) Arsenic: environmental contamination and exposure. In: Arsenic: sources, environmental impact, toxicity and human health. A medical geology perspective. Nova Publishers, Hauppauge, NY, pp 3-38

Sultana F (2013) Water, technology, and development: transformations of development technonatures in changing waterscapes. Environ Plan D Soc Sp 31:337-353. https://doi. org/10.1068/d20010

Sun G (2004) Arsenic contamination and arsenicosis in China. Toxicol Appl Pharmacol 198:268-271 
Sun SK, Chen Y, Che J et al (2018) Decreasing arsenic accumulation in rice by overexpressing $O S N I P 1 ; 1$ and $O S N I P 3 ; 3$ through disrupting arsenite radial transport in roots. New Phytol 219:641-653. https://doi.org/10.1111/nph.15190

Suriyagoda LDB, Dittert K, Lambers H (2018) Mechanism of arsenic uptake, translocation and plant resistance to accumulate arsenic in rice grains. Agric Ecosyst Environ 253:23-37

Takahashi E (1968) Silica as a nutrient to the rice plant. Jpn Agric Res Q 3:1

Talukder ASMHM, Meisner CA, Sarkar MAR, Islam MS (2011) Effect of water management, tillage options and phosphorus status on arsenic uptake in rice. Ecotoxicol Environ Saf 74:834-839. https://doi.org/10.1016/j.ecoenv.2010.11.004

Tareq SM, Islam SMN, Rahmam MM, Chowdhury DA (2015) Arsenic pollution in groundwater of Southeast Asia: an overview on mobilization process and health effects. Bangladesh J Environ Res 8:47-67

Thomas DJ (2013) The die is cast: arsenic exposure in early life and disease susceptibility. Chem Res Toxicol 26:1778-1781

Tripathi P, Tripathi RD, Singh RP et al (2013) Arsenite tolerance in rice (Oryza sativa L.) involves coordinated role of metabolic pathways of thiols and amino acids. Environ Sci Pollut Res 20:884-896. https://doi.org/10.1007/s11356-012-1205-5

Tuli R, Chakrabarty D, Trivedi PK, Tripathi RD (2010) Recent advances in arsenic accumulation and metabolism in rice. Mol Breed 26:307-323. https://doi.org/10.1007/s11032-010-9412-6

Vahidnia A, Van Der Voet GB, De Wolff FA (2007) Arsenic neurotoxicity: a review. Hum Exp Toxicol 26:823-832

Vahter M, Concha G (2001) Role of metabolism in arsenic toxicity. Pharmacol Toxicol 89:1-5. https://doi.org/10.1111/j.1600-0773.2001.890101.x

Vaughan DJ (2006) Arsenic. Elements 2:71-75. https://doi.org/10.2113/gselements.2.2.71

Wang P, Zhang W, Mao C et al (2016) The role of OsPT8 in arsenate uptake and varietal difference in arsenate tolerance in rice. J Exp Bot 67:6051-6059. https://doi.org/10.1093/jxb/erw362

Wang FZ, Chen MX, Yu LJ et al (2017) OsARM1, an R2R3 MYB transcription factor, is involved in regulation of the response to arsenic stress in rice. Front Plant Sci 8:1868. https://doi. org/10.3389/fpls.2017.01868

Wenzel WW, Alloway BJ (2013) Chapter 9 Arsenic. Springer, Dordrecht

$\mathrm{Wu} \mathrm{C}, \mathrm{Ye} \mathrm{Z}, \mathrm{Li} \mathrm{H}$ et al (2012) Do radial oxygen loss and external aeration affect iron plaque formation and arsenic accumulation and speciation in rice? J Exp Bot 63:2961-2970. https://doi. org/10.1093/jxb/ers017

Wu LB, Shhadi MY, Gregorio G et al (2014) Genetic and physiological analysis of tolerance to acute iron toxicity in rice. Rice 7:8. https://doi.org/10.1186/s12284-014-0008-3

Wu X, Cobbina SJ, Mao G et al (2016) A review of toxicity and mechanisms of individual and mixtures of heavy metals in the environment. Environ Sci Pollut Res 23:8244-8259. https:// doi.org/10.1007/s11356-016-6333-X

Wu LB, Ueda Y, Lai SK, Frei M (2017) Shoot tolerance mechanisms to iron toxicity in rice (Oryza sativa L.). Plant Cell Environ 40:570-584. https://doi.org/10.1111/pce.12733

Xu J, Shi S, Wang L et al (2017) OsHAC4 is critical for arsenate tolerance and regulates arsenic accumulation in rice. New Phytol 215:1090-1101. https://doi.org/10.1111/nph.14572

Yamazaki S, Ueda Y, Mukai A et al (2018) Rice phytochelatin synthases OsPCS1 and OsPCS2 make different contributions to cadmium and arsenic tolerance. Plant Direct 2:e00034. https:// doi.org/10.1002/pld3.34

Yang Y, Zhang A, Chen Y et al (2018) Impacts of silicon addition on arsenic fractionation in soils and arsenic speciation in Panax notoginseng planted in soils contaminated with high levels of arsenic. Ecotoxicol Environ Saf 162:400-407. https://doi.org/10.1016/j.ecoenv.2018.07.015

Yang Y, Hu H, Fu Q et al (2020) Phosphorus regulates As uptake by rice via releasing As into soil porewater and sequestrating it on Fe plaque. Sci Total Environ 738:139869. https://doi. org/10.1016/j.scitotenv.2020.139869 
Yu S, Ali J, Zhang C et al (2020) Genomic breeding of green super rice varieties and their deployment in Asia and Africa. Theor Appl Genet 133:1427-1442

Zavala YJ, Duxbury JM (2008) Arsenic in rice: I. Estimating normal levels of total arsenic in rice grain. Environ Sci Technol 42:3856-3860. https://doi.org/10.1021/es702747y

Zhang J, Zhu YG, Zeng DL et al (2008) Mapping quantitative trait loci associated with arsenic accumulation in rice (Oryza sativa). New Phytol 177:350-356. https://doi. org/10.1111/j.1469-8137.2007.02267.x

Zhao FJ, Ma JF, Meharg AA, McGrath SP (2009) Arsenic uptake and metabolism in plants. New Phytol 181:777-794. https://doi.org/10.1111/j.1469-8137.2008.02716.x

Zhao FJ, Ago Y, Mitani N et al (2010a) The role of the rice aquaporin Lsi 1 in arsenite efflux from roots. New Phytol 186:392-399. https://doi.org/10.1111/j.1469-8137.2010.03192.x

Zhao FJ, McGrath SP, Meharg AA (2010b) Arsenic as a food chain contaminant: mechanisms of plant uptake and metabolism and mitigation strategies. Annu Rev Plant Biol 61:535-559. https://doi.org/10.1146/annurev-arplant-042809-112152

Zhao FJ, Stroud JL, Khan AA, McGrath SP (2012) Arsenic translocation in rice investigated using radioactive 73As tracer. Plant Soil 350:413-420. https://doi.org/10.1007/s11104-011-0926-4

Zhao FJ, Zhu YG, Meharg AA (2013) Methylated arsenic species in rice: geographical variation, origin, and uptake mechanisms. Environ Sci Technol 47:3957-3966. https://doi.org/10.1021/ es304295n

Zhu YG, Williams PN, Meharg AA (2008) Exposure to inorganic arsenic from rice: a global health issue? Environ Pollut 154:169-171. https://doi.org/10.1016/j.envpol.2008.03.015

Open Access This chapter is licensed under the terms of the Creative Commons Attribution 4.0 International License (http://creativecommons.org/licenses/by/4.0/), which permits use, sharing, adaptation, distribution and reproduction in any medium or format, as long as you give appropriate credit to the original author(s) and the source, provide a link to the Creative Commons license and indicate if changes were made.

The images or other third party material in this chapter are included in the chapter's Creative Commons license, unless indicated otherwise in a credit line to the material. If material is not included in the chapter's Creative Commons license and your intended use is not permitted by statutory regulation or exceeds the permitted use, you will need to obtain permission directly from the copyright holder.

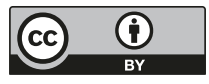

